RFCFIVED

Annual ${ }^{A P R} 301998$

Report of

OSTI

The Columbia

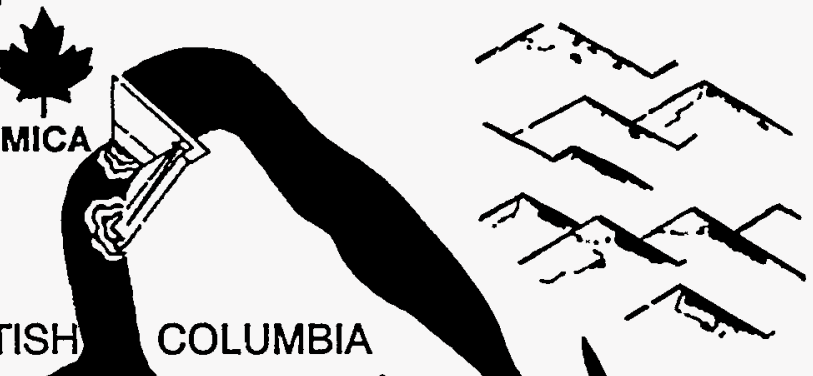

River Treaty,

Canadian and

United States

Entities
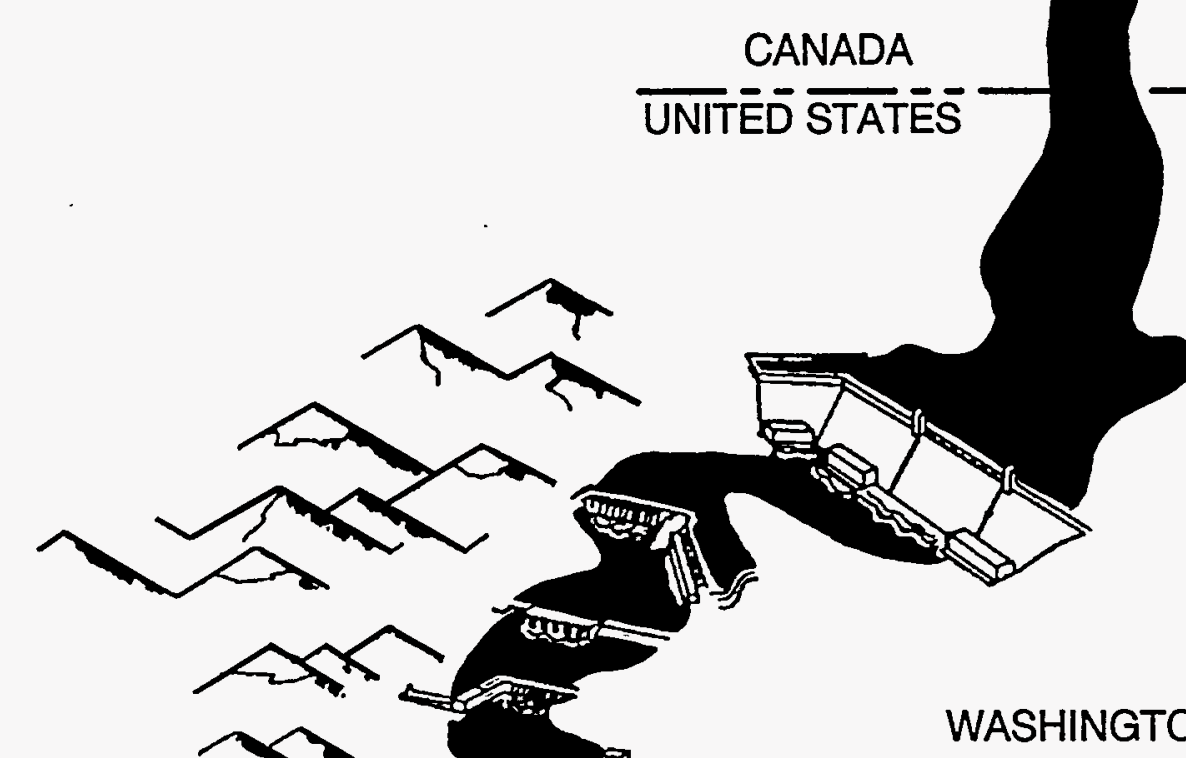

Pon

WASHINGTON

KEENLEYSIDE

CANADA
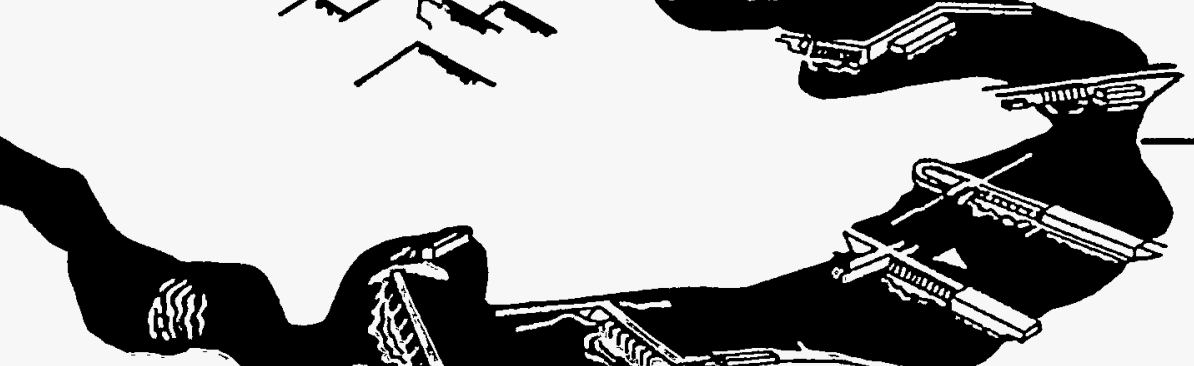



\section{ANNUAL REPORT OF THE COLUMBIA RIVER TREATY CANADIAN AND UNITED STATES ENTITIES}

FOR THE PERIOD

1 OCTOBER 1994 - 30 SEPTEMBER 1995

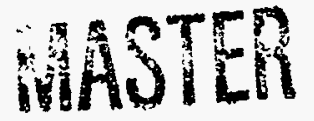




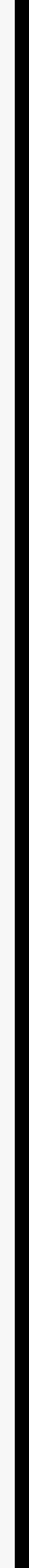




\section{Executive Summary}

\section{Entity Agreements}

Agreements approved by the Entities during the period of this report include:

- Columbia River Treaty Entity Agreement on the Preparation of the 1998/1999, 1999/2000, and 2000/2001 Assured Operating Plan and Determination of Downstream Power Benefit Studies, executed 5 April 1995.

- $\quad$ Columbia River Treaty Entity Agreement on the Assured Operating Plan and Determination of Downstream Power Benefit Studies for the 1998/1999 Operating Year, executed 5 April 1995.

- $\quad$ Columbia River Treaty Entity Agreement on the Assured Operating Plan and Determination of Downstream Power Benefit Studies for the 1999/2000 Operating Year, executed 5 April 1995.

- $\quad$ Columbia River Treaty Entity Agreement On Operation of Treaty Storage for Non-Power Uses for January 1 through July 31, 1995, executed 13 June 1995.

\section{System Operation}

The coordinated system filled to 74.7 percent of Actual Energy Regulation (AER) storage capacity by 31 July 1994. As a result, third year firm energy load carrying capability (FELCC) was adopted for the 1994-95 operating year. Actual storage capacity was filled to 77 percent. The system continued to proportionally draft from August through February to meet FELCC. During March through July, the system load could be met operating to the Energy Content Curves (ECC), except for second half of April when proportional draft was required to meet FELCC.

The 1 January 1995 water supply forecast for the Columbia River at The Dalles (January-July) was 101.0 maf, or 95 percent of average. From this data, the Federal System was operated conservatively to ensure that approximately 3.25 maf above the energy content curve (ECC) would be provided for the 1995 juvenile fish flow augmentation. Energy was purchased by BPA to keep the reservoirs (Arrow, Grand Coulee and Libby) above PDP consistent with the Entities Non-power agreement. Although temperatures and rainfall over most spring months were above normal, the month of February's precipitation at 89 percent of normal, resulted in dropping forecasted runoff until April when 150 percent 
of normal rains turned the trend upward. After near normal May rainfall turned the forecast downward, 150 percent of normal June rainfall resulted in an increased July forecast. The actual January-July observed runoff was 104.0 maf, or 98 percent of average. The peak daily average flow observed at The Dalles was 296,000 cfs on 19 May 1995.

Using Water Budget storage, Flow Augmentation storage, and other flexibility not covered by the Treaty, the lower Columbia River flow was regulated for juvenile fish between 10 April and 31 August, based o n recommendations of the "Technical Management Team" (TMT) consisting of representatives from five U.S. Federal agencies. State fishery agencies and Indian tribes also provided input at the TMT meetings. This information was usually provided through the Fish Passage Center (FPC). The TMT's Executive and Technical groups make recommendations to the two operating agencies (Corps of Engineers and Bureau of Reclamation) on dam and reservoir operations to optimize passage conditions for juvenile and adult anadromous salmonids in accordance with the National Marine Fisheries Service's Biological Opinion (BiOp). Each year, the TMT will also prepare a Water Management Plan to meet various fishery, flow, reservoir operation, and other objectives.

Coordinated System storage energy as of 31 July 1995 reached a level in the Actual Energy Regulation of 89 percent of full. This value was used to determine the Firm Energy Load Carrying Capability (FELCC), with first-year FELCC being adopted for the 1995-96 operating year. The actual reservoir refill was 91 percent of full, slightly above the calculated AER; the difference providing some operating room in the reservoirs. This year's refill was the highest since 1991, giving the reservoir system the flexibility to operate less conservatively than has been required for the past several years when reservoirs refilled to only the 70-77 percent range.

From 1 August 1994 through 31 March 1995 generation at downstream projects in the United States, delivered to the Columbia Storage Power Exchange (CSPE) participants under the Canadian Entitlement Exchange Agreement, was approximately 279 average megawatts at rates up to 666 megawatts. From 1 April through 31 July 1995 the delivery was 268 average megawatts, at rates up to 576 megawatts. All CSPE power was used to meet Pacific Northwest loads.

Between 1 August 1994 and 31 July 1995, the Canadian Entity delivered 2.0 average megawatts of energy and no dependable capacity to the U.S. Entity under the Canadian Entitlement Purchase Agreement. 
Also, between 1 August 1994 and 31 July 1995, the U.S. Entity delivered 20.9 megawatts of energy minus 3 percent losses, and no dependable capacity to the Canadian Entity. This was done in accordance with the 1994-95 DOP and is based on the firm energy shifting in the Assured Operating Plan.

\section{Treaty Project Operation}

The Treaty projects, Duncan, Mica, and Arrow, were operated throughout the year in accordance with the 1994-95 Detailed Operating Plan, the Flood Control Operating Plan, and the nonpower uses agreement. Throughout the year, Libby reservoir was operated in accordance with the flood control operating plan, as amended by the U.S.Army Corps of Engineers (ACE) "Review of Flood Control, Columbia River Basin, Columbia River \& Tributaries Study, CRT-63",dated June 1981, and the Entity agreement on Non-Power Uses. During a portion of the year, Libby was operated for power requirements according to the DOP, and during the remainder of the operating year Libby operated for storage and releases required for endangered White Sturgeon and Salmon as required by both the U.S. Fish and Wildlife Service and the National Marine Fishery Service Biological Opinions. The Canadian Entity has given notice that it considers the BiOp fishery operation to be inconsistent with the DOP and Columbia River Treaty.

Mica Treaty storage was 5.4 maf on 31 July 1994, and with continued storing, reached 6.4 maf or 91 percent of full content on 31 August 1994. The actual reservoir elevation reached a high of Elev. 2437.9 feet (37.1 feet below full) on 15 August. By 31 December, Treaty storage was 1.5 maf and the observed reservoir level had dropped to Elev. 2402.4 feet. Treaty storage reached its lowest level on 1 May 1995 at -1.0 maf. The reservoir reached its lowest level for the 1994-95 water year, Elev. 2374.8 feet, on 2 May 1995, 24 feet higher than the previous year. From then on, Mica's Treaty storage refilled, reaching 100 percent full (3528 ksfd or 7.0 maf) on 13 September 1995. The maximum level for 1995, Elev. 2470.7 feet, 4.3 feet below full pool, was reached on 21 August 1995.

The Arrow Treaty storage account started the $1994-95$ operating year.(1 August 1994) at $5.8 \mathrm{maf}$, or 82 percent of full, following its 1994 operating year maximum level of Elev. 1426.5 feet on 26 July 1994. The reservoir was drafted to Elev. 1403.1 feet on 31 December 1994 with a Treaty storage of 2.9 maf or 41 percent of full. During January through July, Arrow operated under an Entity agreement on the operation of Treaty storage for non-power uses. This agreement allowed the operation of Keenleyside Dam to be coordinated for fisheries and recreation benefit on both sides of the border, and made it possible for 
BCHydro to meet a flow order imposed by the Canadian federal Department of Fisheries and Oceans. Drafting continued during January through March with releases of Non-Treaty storage to maintain a minimum flow of $25 \mathrm{kcfs}$ during February and March to avoid dewatering mountain whitefish eggs below Keenleyside. This resulted in Arrow reaching its lowest level of the year Elev. 1386.6 feet on 30 March 1995. Arrow Treaty storage reached its annual minimum on 4 April at 1.9 maf or 27 percent full. During April, Arrow discharges were held at $15 \mathrm{kcfs}$ to ensure rainbow trout would not spawn at high river levels. This caused Arrow to fill to Elev. 1397.6 feet by 30 April. During mid-May through mid-June, Keenleyside outflow was reduced to $5 \mathrm{kcfs}$ as high spring runoff in the Kootenay River caused a backwater at the Norns Creek fan. The Arrow reservoir filled to Elev. 1440.6 feet by 30 June, the time when all trout eggs are assumed to have hatched. During July, Keenleyside discharge was increased as Treaty storage neared full. The Arrow Reservoir reached its highest level of Elev. 1442.8 feet on 11 July 1995 . The Arrow Treaty storage reached 99 percent full also on that date. During August, increased outflows drafted Arrow to Elev. 1433.7 feet. Further drafting to Elev. 1429.0 feet was done by 30 September 1995 with Treaty storage at 5.8 maf or 82 percent of full.

Duncan reservoir filled by the end of the 1993-94 operating year with a reservoir level of Elev. 1891.5 feet on 31 July 1994. The project began drafting on 6 August to allow Arrow discharge to be reduced and to support the Kootenay Lake level. During most of September through December, Duncan was used to support Kootenay Lake and by 31 December, Duncan reservoir had drafted to Elev. 1810.1 feet (11 percent of full), the lowest level on record for this time of the year. With Libby drafting heavily in January, Duncan outflows were reduced to minimum flow. Early February saw the Libby outflow reduced resulting in Duncan's remaining storage being drafted out through April. Duncan reached its lowest level during the 1994-95 operating year of Elev. 1794.7 feet, on 21 April 1995. Minimum release during MayJuly helped refill the reservoir to Elev. 1888.5 feet ( 3.5 feet from full) by 31 July 1995 . With outflows increased to near inflow, the pool continued a slow filling to full pool of Elev. 1892.0 feet by 29 August. During September, outflow was increased to $8 \mathrm{kcfs}$ to begin drafting Duncan and filling Kootenay Lake. By 30 September 1995, Duncan had been drafted to Elev. 1875.8 feet.

During the 1993-94 operating year, Libby reached its maximum level of Elev. 2444.4 feet (14.6 feet below full pool) on 31 July 1994. By 5 September, the level had reached its peak summer level of Elev. 2447.25 feet. An outflow of $4 \mathrm{kcfs}$ was maintained through 7 October for Montana Department of Fish, Wildlife, and Parks continuation of fishery research work. During October through December, Libby 
was operated partly for U.S. power requirements to store water for later U.S. Fish and Wildlife Service's Biological Opinion operations,_by releasing 12-20 kcfs on weekdays and $4 \mathrm{kcfs}$ on weekends, drafting Libby reservoir to its flood control level of Elev. 2411 feet by 31 December. With a water supply forecast being 95 percent of normal, Libby outflow during January was in the range of 12-19 kcfs to draft to the flood control level of Elev. 2387 feet by 31 January. Due to decreasing runoff volume forecasts, Libby outflow was reduced to its minimum flow of $4 \mathrm{kcfs}$ on 4 February 1995. A minimum pool level for the year, Elev. 2380.8 feet, was reached on 18 February. The 15 March pool level was Elev. 2381.5 feet, 5.4 feet below the flood control level of Elev. 2386.9 feet. On 29 April, Libby began operating in accordance with the U.S. Fish and Wildlife Service's Biological Opinion to enhance white sturgeon spawning with the outflow being adjusted between 4 and $10 \mathrm{kcfs}$ to provide a flow of $15 \mathrm{kcfs}$ at Bonners Ferry. Between 13 and 15 May, based on observed sturgeon spawning, Libby outflow was ramped up to $20 \mathrm{kcfs}$, turbine capacity of four available units at Libby this year. The $20 \mathrm{kcfs}$ was held through $26 \mathrm{June}$ (42 days), when the outflow was stepped down to $8.5 \mathrm{kcfs}$ by 5 July to maintain an $11 \mathrm{kcfs}$ flow at Bonners Ferry through 15 July (11 days). During 18 July - 4 August, after TMT recommended a $20 \mathrm{kcfs}$ flow from Libby for lower Columbia River salmon augmentation, a Libby-Arrow transfer was agreed upon to reduce releases at Libby to reduce spill at Canada's lower Kootenay River projects. The maximum level for the season was Elev. 2456.8 feet, 2.2 feet below full pool, reached on 30 July 1995. The first two weeks of August saw Libby releasing $16 \mathrm{kcfs}$. The last half of August through 13 September had Libby releasing inflow, but less than $10 \mathrm{kcfs}$, as MFW\&P was conducting fishery research. By 14 September, outflow was reduced to 4 kcfs for further MFW\&P fishery research, boat ramp work at Bonners Ferry, and bridge pier removal downstream of Libby Dam. The observed pool level on 30 September 1995 was Elev. 2453.8 feet. 


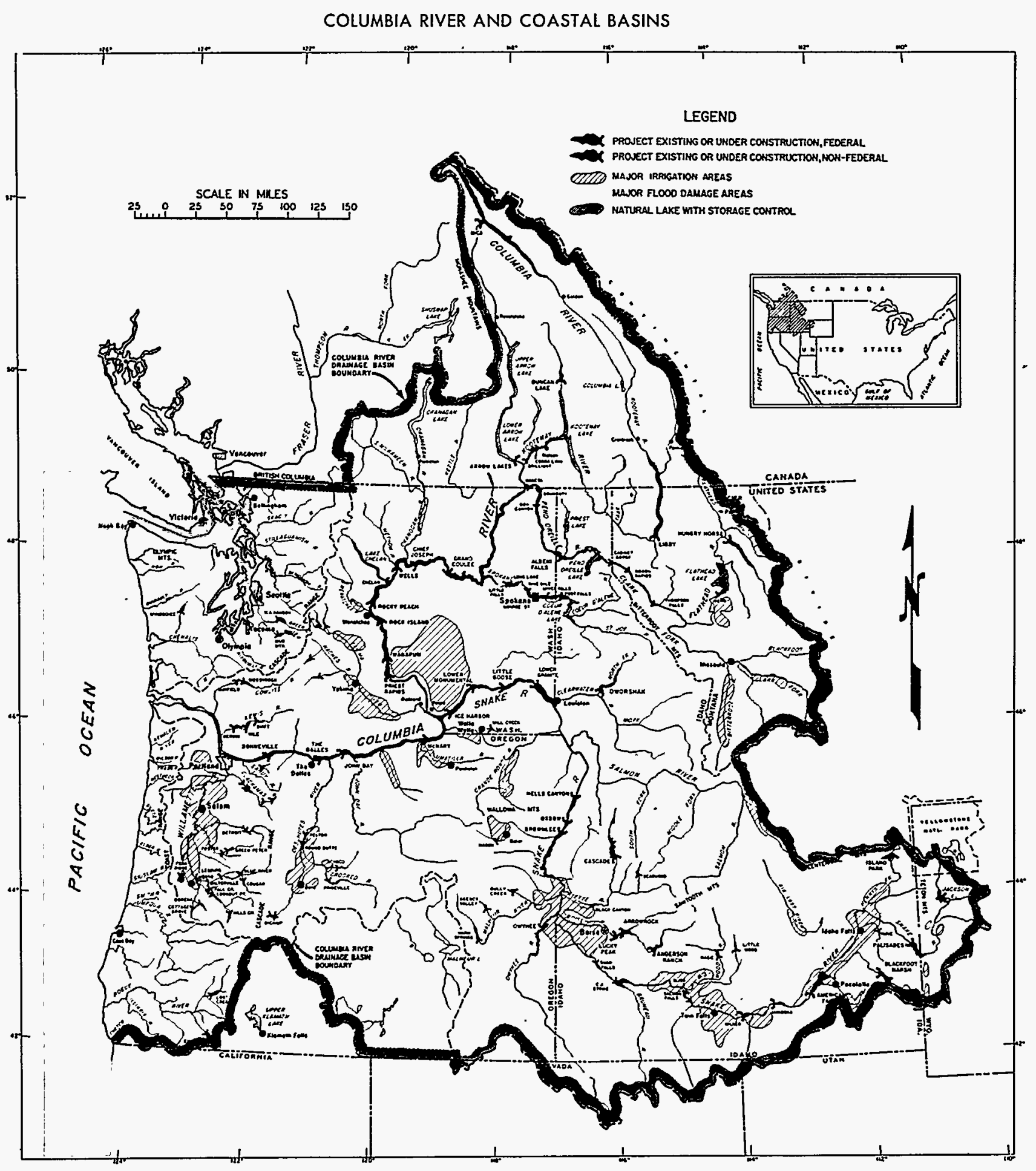


viii 


\section{Report of The Columbia River Treaty Entities \\ Contents}

Page

EXECUTIVE SUMMARY

Entity Agreements

System Operation

Treaty Project Operation

i

i

i

iii

I. INTRODUCTION 1

II. TREATY ORGANIZATION 3

Entities $\quad 3$

Entity Coordinators $\quad 4$

Columbia River Treaty Operating Committee 5

Columbia River Treaty Hydrometeorological Committee 6

Permanent Engineering Board 7

PEB Engineering Committee $\quad 8$

$\begin{array}{ll}\text { International Joint Commission } & 8\end{array}$

III. OPERATING ARRANGEMENTS 11

Power and Flood Control Operating Plans 11

$\begin{array}{ll}\text { Assured Operating Plan } & 12\end{array}$

Determination of Downstream Power Benefits 12

$\begin{array}{ll}\text { Detailed Operating Plan } & 12\end{array}$

Entity Agreements 13

Long Term Non-Treaty Storage Contract 13

IV. WEATHER AND STREAMFLOW 15

Weather 15

Streamflow 16

Seasonal Runoff Forecasts and Volumes $\quad 18$

$\begin{array}{ll}\text { V. RESERVOIR OPERATION } & 21\end{array}$

General $\quad 21$

Mica Reservoir $\quad 22$

Revelstoke Reservoir 23

Arrow Reservoir $\quad 23$

Duncan Reservoir 25

Libby Reservoir $\quad 26$

Kootenay Lake $\quad 27$

Storage Transfer Agreements 28 


\section{Report of The Columbia River Treaty Entities \\ Contents (continued)}

Page

VI. POWER AND FLOOD CONTROL ACCOMPLISHMENTS 29

General $\quad 29$

Power Deliveries $\quad 30$

Power Operations $\quad 30$

Flood Control $\quad 34$

FIGURES

Columbia River and Coastal Basins vii

Columbia River Treaty Organization 9

\section{TABLES}

1 Unregulated Runoff Volume Forecasts 35

2 Variable Refill Curve, Mica Reservoir 36

3 Variable Refill Curve, Arrow Reservoir 37

4 Variable Refill Curve, Duncan Reservoir 38

5 Variable Refill Curve, Libby Reservoir 39

6 Initial Controlled Flow Computation $\quad 40$

\section{CHARTS}

1 Seasonal Precipitation 41

2 Snowpack $\quad 42$

3 Temperature \& Precipitation Winter Indices for Basin

4 Temperature and Precipitation Summer Indices for Basin Above The Dalles 44

5 Temperature and Precipitation Summer Indices for Basin In In Canada 45

6 Regulation of Mica 46

7 Regulation of Arrow 47

8 Regulation of Duncan 48

9 Regulation of Libby 49

10 Regulation of Kootenay Lake $\quad 50$

11 Columbia River at Birchbank 51

12 Regulation of Grand Coulee $\quad 52$

13 Columbia River at The Dalles, Jul 93-Jul 94

14 Columbia River at The Dalles, Apr-Jul 94

15 Relative Filling, Arrow and Grand Coulee 55 


\section{Introduction}

This annual Columbia River Treaty Entity Report is for the 1995 Water Year, 1 October 1994 through 30 September 1995. It includes information on the operation of Mica, Arrow, Duncan, and Libby reservoirs during that period with additional information covering the reservoir system operating year, 1 August 1994 through 31 July 1995. The power and flood control effects downstream in Canada and the United States are described. This report is the twenty-ninth of a series of annual reports covering the period since the ratification of the Columbia River Treaty in September 1964.

Duncan, Arrow, and Mica reservoirs in Canada and Libby reservoir in the United States of America were constructed under the provisions of the Columbia River Treaty of January 1961. Treaty storage in Canada is required to be operated for the purposes of flood control and increasing hydroelectric power generation in Canada and the United States of America. In 1964, the Canadian and the United States governments each designated an Entity to formulate and carry out the operating arrangements necessary to implement the Treaty. The Canadian Entity is the British Columbia Hydro and Power Authority (B.C. Hydro). The United States Entity is the Administrator of the Bonneville Power Administration (BPA) and the Division Engineer of the North Pacific Division, Army Corps of Engineers (ACE).

The following is a summary of key features of the Treaty and related documents:

1. Canada is to provide 15.5 million acre-feet (maf) of usable storage. (This has been accomplished with 7.0 maf in Mica, 7.1 maf in Arrow and 1.4 maf in Duncan.)

2. For the purpose of computing downstream benefits the U.S. hydroelectric facilities will be operated in a manner that makes the most effective use of the improved streamflow resulting from operation of the Canadian storage.

3. The U.S. and Canada are to share equally the additional power generated in the U.S. resulting from operation of the Canadian storage.

4. The U.S. paid Canada a lump sum of the $\$ 64.4$ million (U.S.) for expected flood control benefits in the U.S. resulting from operation of the Canadian storage.

5. The U.S. has the option of requesting the evacuation of additional flood control space above that specified in the Treaty, for a payment of $\$ 1.875$ million (U.S.) for each of the first four requests for this "on-call" storage. 
6. The U.S. constructed Libby Dam with a reservoir that extends $\mathbf{4 2}$ miles into Canada and for which Canada made the land available.

7. Both Canada and the United States have the right to make diversions of water for consumptive uses and, in addition, after September 1984 Canada has the option of making for power purposes specific diversions of the Kootenay River into the headwaters of the Columbia River.

8. Differences arising under the Treaty which cannot be resolved by the two countries may be referred to either the International Joint Commission (IJC) or to arbitration by an appropriate tribunal.

9. The Treaty shall remain in force for at least 60 years from its date of ratification, 16 September 1964.

10. In the Canadian Entitlement Purchase Agreement of 13 August 1964, Canada sold its entitlement to downstream power benefits to the United States for 30-years beginning at Duncan on 1 April 1968, at Arrow on 1 April 1969, and at Mica on 1 April 1973.

11. Canada and the U.S. are each to appoint Entities to implement Treaty provisions and are to jointly appoint a Permanent Engineering Board (PEB) to review and report on operations under the Treaty. 


\title{
II Treaty Organization
}

\section{Entities}

There were two meetings of the Columbia River Treaty Entities (including the Canadian and U.S. Entities and Entity Coordinators) during the year on the morning of 1 February 1995 in Victoria, British Columbia,-and on the morning of 21 March 1995 in Portland, Oregon. The members of the two Entities at the end of the period of this report were:

\author{
UNITED STATES ENTITY \\ Mr. Randall W. Hardy, Chair \\ Administrator \& Chief Executive Officer \\ Bonneville Power Administration \\ Department of Energy \\ Portland, Oregon \\ Major General Russell L. Fuhrman, Member \\ Division Engineer \\ North Pacific Division \\ Army Corps of Engineers \\ Portland, Oregon \\ CANADIAN ENTITY \\ Mr. John N. Laxton, Chair \\ British Columbia \\ Hydro and Power Authority \\ Vancouver, British Columbia \\ MG Fuhrman succeeded MG Emest J. Harrell effective 19 July 1995.
}

The Entities have appointed Coordinators and two joint standing committees to assist in Treaty implementation activities. These are described in subsequent paragraphs. The primary duties and responsibilities of the Entities as specified in the Treaty and related documents are:

1. Plan and exchange information relating to facilities used to obtain the benefits contemplated by the Treaty.

2. Calculate and arrange for delivery of hydroelectric power to which Canada is entitled and the amounts payable to the U.S. for standby transmission services.

3. Operate a hydrometeorological system.

4. Assist and cooperate with the Permanent Engineering Board in the discharge of its functions.

5. Prepare hydroelectric and flood control operating plans for the use of Canadian storage.

6. Prepare and implement detailed operating plans that may produce results more advantageous to both countries than those that would arise from operation under assured operating plans.

7. The Treaty provides that the two governments may, by an exchange of notes, empower or charge the Entities with any other matter coming within the scope of the Treaty. 


\section{Entity Coordinators}

The Entities have appointed members of their respective staffs to serve as coordinators or focal points on Treaty matters within their organizations.

The members are:

\section{UNITED STATES ENTITY COORDINATORS}

Judith A. Johansen, Coordinator

Vice President, Generation Supply

Bonneville Power Administration

Portland, Oregon

John E. Velehradsky, Coordinator

Director, Engineering \& Technical Services

North Pacific Division

Army Corps of Engineers

Portland, Oregon

Pamela A. Kingsbury, Secretary

Resource Optimization

Hydro/Thermal Operations

Bonneville Power Administration

Vancouver, Washington

\section{CANADIAN ENTITY COORDINATOR}

T. J. (Tim) Newton, Coordinator BC Hydro and Power Authority Vancouver, British Columbia

Graeme L. Simpson, Secretary

Manager, Resource Optimization Dept. BC Hydro and Power Authority Vancouver, British Columbia

Mr. Newton was appointed to succeed Mr. Kenneth Epp effective 1 December 1994.

Ms. Johansen succeeded Ms. Sue Hickey effective 31 January 1995.

Mr. Velehradsky was appointed to succeed Mr. David Geiger effective 27 February 1995. 


\section{Columbia River Treaty Operating Committee}

The Operating Committee was established in September 1968 by the Entities and is responsible for preparing and implementing operating plans as required by the Columbia River Treaty, making studies and otherwise assisting the Entities as needed. The Operating Committee consists of eight members as follows:

UNITED STATES SECTION

Mark Maher, BPA, Co-Chair

Nicholas A. Dodge, ACE, Co-Chair

Russell L. George, ACE

Steven.A. Montfort, BPA

\section{CANADIAN SECTION}

Ralph D. Legge, $\mathrm{BCH}$, Chair

Kenneth R. Spafford, BCH

Henry C. Mark, BCH

Thomas K. Siu, BCH

Mr. Legge was appointed Chair of the Canadian Section to succeed Mr. Tim Newton, effective 1 February 1995.

Dr. Siu was appointed to fill the vacant position on the Canadian Section on 25 September 1995.

There were six meetings of the Operating Committee during the year. The dates, places and number of persons attending those meetings were:

Date

8 November 1994

19 January 1995

16 March 1995

11 May 1995

12 July 1995

19 September 1995
Location

Vancouver, B.C.

Portland, OR.

Vancouver, B.C.

Bonneville Dam, OR.

Vancouver, B.C.

Vancouver, WA.
Attendees

\section{3}

17

18

.18

19

18

The Operating Committee coordinated the operation of the Treaty storage in accordance with the current hydroelectric and flood control operating plans. This aspect of the Committee's work is described in following sections of this report which have been prepared by the Committee with the assistance of others. During the period covered by this report, the Operating Committee completed the 1998/1999 and 1999/00 Assured Operating Plan and Determination of Downstream Power Benefits (AOP/DDPB) documents. The Determination of Downstream Power Benefits for the respective Assured Operating Plans for 1998/99 and 1999/00 each contain both a Canadian and a U.S. determination of the dependable capacity component for the Canadian Entitlement, and further discussions are required between the Entities to agree on a single value. The Operating Committee also completed the 1 August 1995 through 31 July 1996 Detailed Operating Plan for Columbia River Treaty Storage. 


\section{Columbia River Treaty Hydrometeorological Committee}

The Hydrometeorological Committee was established in September 1968 by the Entities and is responsible for planning and monitoring the operation of data facilities in accord with the Treaty and otherwise assisting the Entities as needed. The Committee consists of four members as follows:

UNITED STATES SECTION

Gregory K. Delwiche, BPA Chair

Peter F. Brooks, ACE, Member
CANADIAN SECTION

Brian H. Fast, BCH, Chair

Heiki Walk, BCH, Member

There was one meeting of the Hydrometeorological Committee, on 3 November 1994, in Portland, OR. The committee reviewed the 1994 volume forecast results, hydromet station changes, and developments in telemetry. There were some data exchange issues which required attention. The U.S. Entity also expressed concern over the dwindling number of Canadian hydromet stations. Both Canadian and U. S. Entities reported that changes in forecast procedures were forthcoming. Both sides will be kept abreast of the others' progress. 


\section{Permanent Engineering Board}

Provisions for the establishment of the Permanent Engineering Board (PEB) and its duties and responsibilities are included in the Treaty and related documents. The members of the PEB are presently:

\section{UNITED STATES SECTION}

John P. Elmore, Chair, Washington, D.C.

Ronald H. Wilkerson, Member Missoula, Montana

Daniel R. Burns, Alternate

Washington, D.C.

Thomas L. Weaver, Alternate

Golden, Colorado

Richard J. DiBuono, Secretary

\section{CANADIAN SECTION}

David Oulton, Chair

Ottawa, Ontario

John Allan, Member

Victoria, British Columbia

Don A. Kasianchuk, Alternate

Victoria, British Columbia

David Burpee, Alternate

Ottawa, Ontario

David Burpee, Secretary

Ottawa, Ontario

Mr. Burns was appointed to replace Mr. Paul Barber as Alternate on 31 March 1995.

Mr. DiBuono was appointed to replace Mr. S.A. Zanganeh as Secretary on 9 August 1995.

In general, the duties and responsibilities of the PEB are to assemble records of flows of the Columbia River and the Kootenay River at the international boundary; report to both governments if there is deviation from the hydroelectric or flood control operating plans, and if appropriate, include recommendations for remedial action; assist in reconciling differences that may arise between the Entities; make periodic inspections and obtain reports as needed from the Entities to assure that Treaty objectives are being met; make an annual report to both governments and special reports when appropriate; consult with the Entities in the establishment and operation of a hydrometeorological system; and, investigate and report on any other Treaty related matter at the request of either government.

The Entities continued their cooperation with the PEB during the past year by providing copies of Entity agreements, operating plans, downstream power benefit computations, corrections to hydrometeorological documents, and the annual Entity report to the Board for their review. The annual joint meeting of the PEB and the Entities was held on the afternoon of 1 February 1995 in Victoria, BC. A special joint meeting of the PEB and the Entities was held on 21 March 1995 in Portland, OR, to discuss progress on Entitlement Agreements. Additional special joint meetings of the PEB and the Entities were held on 9 August 1995 in Ottawa, Ontario and on 26 September 1995 in Portland, OR, to discuss outstanding issues between the Entities resulting from termination of Entitlement discussions. 


\section{PEB Engineering Committee}

The PEB has established a PEB Engineering Committee (PEBCOM) to assist in carrying out its duties. The members of PEBCOM at the end of the period of this report were:

\author{
UNITED STATES SECTION \\ Richard J. DiBuono, Chair \\ Washington, D.C. \\ Gary L. Fuqua, Member \\ Portland, Oregon \\ Earl E. Eiker, Member \\ Washington, D.C. \\ Stephan J. Wright, Alternate Member \\ Washington, D.C. \\ Richard L. Mittelstadt, Alternate Membẹr \\ Portland, Oregon
}

\author{
CANADIAN SECTION \\ R.O. "Neill" Lyons, Chair \\ Vancouver, British Columbia \\ David Burpee, Member \\ Ottawa, Ontario \\ Roger McLaughlin, Member \\ Victoria, British Columbia \\ Bala Balachandran, Member \\ Victoria, British Columbia \\ Bruno Gobeil, Member \\ Ottawa, Ontario
}

Mr. DiBuono was appointed Chair of the U.S. Section to replace Mr. S.A. Zanganeh, effective 31 March 1995.

Mr. Gobeil was appointed as a Member, effective 6 September 1995

\section{International Joint Commission}

The International Joint Commission (IJC) was created under the Boundary Waters Treaty of 1909 between Canada and the U.S. Its principal functions are rendering decisions on the use of boundary waters, investigating important problems arising along the common frontier not necessarily connected with waterways, and making recommendations on any question referred to it by either government. If a dispute concerning the Columbia River Treaty could not be resolved by the Entities or the PEB it may be referred to the IIC for resolution before being submitted to a tribunal for arbitration.

The IJC has appointed local Boards of Control to insure compliance with IJC orders and to keep the IJC currently informed. There are three such boards west of the continental divide. These are the International Kootenay Lake Board of Control, the International Columbia River Board of Control, and the International Osoyoos Lake Board of Control. The Entities and their committees conducted their Treaty activities during the period of this report so that there was no known conflict with IJC orders or rules. 


\section{Columbia River Treaty Organization}

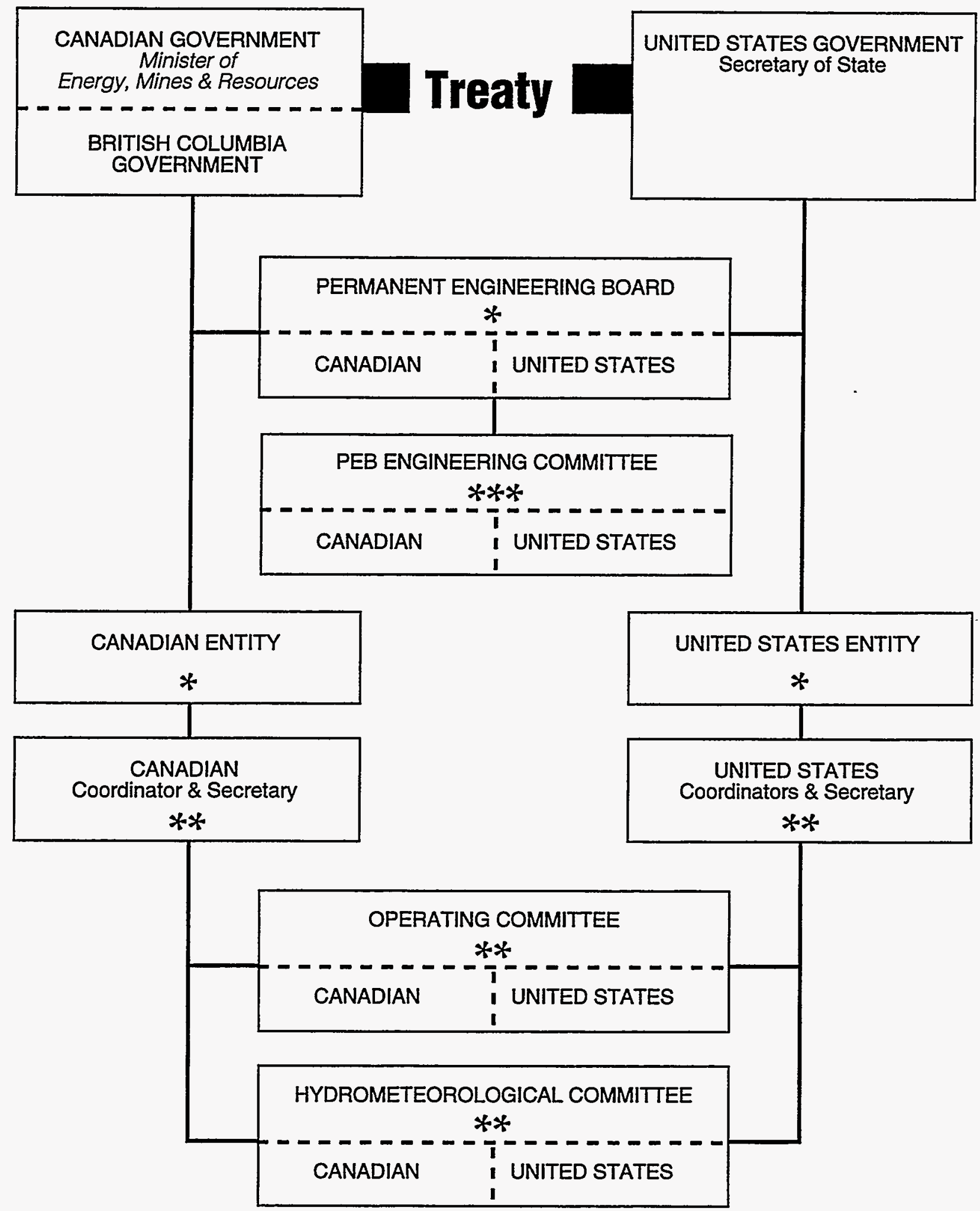

* Established by Treaty

** Established by Entity

*** Established by PEB 


\section{Operating Arrangements}

\section{Power and Flood Control Operating Plans}

The Columbia River Treaty requires that the reservoirs constructed in Canada be operated pursuant to flood control and hydroelectric operating plans developed thereunder. Annex $A$ of the Treaty stipulates that the United States Entity will submit flood control operating plans and that the Canadian Entity will operate in accordance with flood control storage diagrams or any variation which the Entities agree will not be adverse to the desired aim of the flood control plan. Annex $A$ also provides for the development of hydroelectric operating plans five years in advance to furnish the Entities with an Assured Operating Plan for Canadian storage. In addition, Article XIV.2.k of the Treaty provides that a Detailed Operating Plan may be developed to produce more advantageous results through the use of current estimates of loads and resources. The Protocol to the Treaty provides further detail and clarification of the principles and requirements of the Treaty.

The "Principles and Procedures for the Preparation and Use of Hydroelectric Operating Plans" dated December 1991 together with the "Columbia River Treaty Flood Control Operating Plan" dated October 1972, establish and explain the general criteria used to plan and operate Treaty storage during the period covered by this report. These documents were previously approved by the Entities. The flood control Storage Reservation Diagram for Libby contained in the 1972 Flood Control Plan, was amended by agreement of the Operating Committee to that contained in the U.S.Army Corps of Engineers (ACE) "Review of Flood Control, Columbia River Basin, Columbia River \& Tributaries Study, CRT-63",dated June 1981.

The planning and operation of Treaty Storage as discussed on the following pages is for the operating year, 1 August through 31 July. The planning and operating for U.S. storage operated according to the Pacific Northwest Coordination Agreement has been changed to the same period. Most of the hydrographs and reservoir charts in this report are for a 13 month period, July 1994 through July 1995. 


\section{Assured Operating Plan}

The Options for Development of the Detailed Operating Plan, dated January 1991 established Operating Rule Curves for Duncan, Arrow, and Mica during the 1994-95 operating year. The Operating Rule Curves provided guidelines for draft and refill. They were derived from Critical Rule Curves, Assured Refill Curves, Upper Rule Curves, and Variable Refill Curves, consistent with flood control requirements, as described in the 1991 Principles and Procedures document. The Flood Control Storage Reservation Curves were established to conform to the Flood Control Operating Plan of 1972.

\section{Determination of Downstream Power Benefits}

For each operating year, the Determination of Downstream Power Benefits resulting from Canadian Treaty storage is made five years in advance in conjunction with the Assured Operating Plan. For operating year 1994-95 the estimate of benefits resulting from operating plans designed to achieve optimum operation in both countries was less than that which would have prevailed from an optimum operation in the United States only. Therefore, in accordance with Sections 7 and 10 of the Canadian Entitlement Purchase Agreement, the Entities agreed that the United States was entitled to receive 2 average megawatts of energy and no dependable capacity during the period 1 August 1994 through 31 July 1995. Suitable arrangements were made between the Bonneville Power Administration and B.C. Hydro for delivery of this capacity and energy.

\section{Detailed Operating Plan}

During the period covered by this report, the Operating Committee used the 1 August 1994 through 31 July 1995 "Detailed Operating Plan for Columbia River Treaty Storage" (DOP), dated August 1994, and the 1 August 1995 through 31 July 1996 DOP dated August 1995, to guide storage operations. The DOP established criteria for determining the Operating Rule Curves for use in actual operations. Except for minor changes at Arrow during the spring months, the DOP used the AOP critical rule curves for Canadian Projects. The Variable Refill Curves and flood control requirements subsequent to 1 January 1995 were determined on the basis of seasonal volume nunoff forecasts during actual operation. Results of the Actual Energy Regulation were used to determine the triggering of releases from Mica. The regulation of the Canadian storage was conducted by the Operating Committee on a weekly basis throughout the year. 


\section{Entity Agreements}

During the period covered by this report, five agreements were approved by the Entities. The following tabulation indicates the date each of these were signed and gives a description of the agreement:

Date Agreement

Signed by Entities

Description

5 April 1995

Columbia River Treaty Entity Agreement on the Preparation of the 1998/1999, 1999/2000, and 2000/2001 Assured Operating Plan and Determination of Downstream Power Benefit Studies.

5 April 1995

Columbia River Treaty Entity Agreement on the Assured Operating Plan and Determination of Downstream Power Benefits for the 1998/1999 Operating Year.

5 April 1995

Columbia River Treaty Entity Agreement on the Assured Operating Plan and Determination of Downstream Power Benefits for the 1999/2000 Operating Year.

13 June 1995

Columbia River Treaty Entity Agreement on Operation of Treaty Storage for Non-power Uses for January 1 through July 31, 1995.

\section{Long Term Non-Treaty Storage Contract}

In accordance with the 9 July 1990 Entity Agreement which approved the contract between B.C. Hydro and BPA relating to the initial filling of non-Treaty storage, coordinated use of non-Treaty storage, and Mica and Arrow refill enhancement, the Operating Committee monitored the storage operations made under this Agreement throughout the operating year to insure that they did not adversely impact operation of Treaty storage required by the Detailed Operating Plan. 


\section{Weather and Streamflow}

\section{Weather}

The 1995 Water Year was preceded by a warm, dry summer throughout the Columbia River Basin. But as the new water year began, this weather pattern gave way to more seasonal weather which dominated the region throughout most of the snow accumulation season of October - March (Charts 1 and 3). During this period a series of moderate storms, on 3 to 10 day intervals, came from the northern Pacific Ocean and passed over the Columbia Basin. Snowpacks increased quickly throughout November, December, and January due to sustained near-to-below-normal temperatures. In February, a sharp upper air ridge established itself on the coast, ushering in a dryer air mass from the south, with temperatures as much as $15^{\circ} \mathrm{F}$ above normal. This started the melting of the low elevation snowpack (Chart 2). This warm layer was relatively shallow so the mid- and high-elevation snowpacks continued to grow. March saw zonal flow, with its normal temperatures and above normal precipitation, return to the basin. During April and May, temperatures remained slightly below normal. With most of the storms, with their normal precipitation, crossing the southern parts of Oregon and Idaho, below precipitation fell in British Columbia (Charts 4 and 5). Above normal precipitation occurred in the first two weeks in May along this southern storm track. Then the moisture supply to these storms was cut off, resulting in dry weather which lasted through the first three days of June. The Canadian drainages ended this two month period with deficit precipitation while the southern Columbia drainages received above normal amounts. After the first few days of June, and Arctic air mass brought the basin a winter-like storm to the entire Pacific Northwest. It produced temperatures $10^{\circ} \mathrm{F}$ cooler than normal as unseasonably heavy precipitation, adding more supply to the slowly melting snowpack. Cooler than normal weather with near normal rainfall continued the remainder of the summer, interspersed with only a few short warm periods.

The final monthly precipitation indices for the Columbia Basin above The Dalles are shown below for the 1995 Water Year. These indices are based on 60 stations and are computed at the end of each month after all the data are collected. Also shown in the table are the monthly indices as a percent of the 30-year average (1961-1990). 


\section{WY 95 Precipitation Indices}

\begin{tabular}{|c|c|c|c|c|c|}
\hline \multirow[t]{2}{*}{ Month } & \multicolumn{2}{|c|}{ Precipitation } & \multirow[t]{2}{*}{ Month } & \multicolumn{2}{|c|}{ Precipitation } \\
\hline & (in.) & $(\%)$ & & (in.) & $(\%)$ \\
\hline Oct 94 & 2.53 & 154 & Apr 95 & 1.86 & 117 \\
\hline Nov 94 & 3.27 & 120 & May 95 & 1.88 & 99 \\
\hline Dec 94 & 2.85 & 95 & Jun 95 & 2.52 & 139 \\
\hline $\operatorname{Jan} 95$ & 2.98 & 101 & Jul 95 & 1.61 & 148 \\
\hline Feb 95 & 1.88 & 89 & Aug 95 & 1.41 & 114 \\
\hline Mar 95 & 2.72 & 145 & Sep 95 & 1.07 & 70 \\
\hline & & & Water Y & 26.59 & 114 \\
\hline
\end{tabular}

\section{Streamflow .}

The observed inflow and outflow hydrographs for the Treaty reservoirs for the period 1 July 1994 through 31 July 1995 are shown on Charts 6 through 9. Observed flows with the computed unregulated flow hydrographs for the same 13-month period for Kootenay Lake, Columbia River at Birchbank, Grand Coulee, and The Dalles are shown on Charts 10,11,12, and 13, respectively. Chart 14 is a hydrograph of observed and two unregulated flows at The Dalles during the April through July 1995 period, including a plot of flows occurring if regulated only by the Treaty reservoirs.

Composite operating year unregulated streamflows in the basin above The Dalles were higher than last year, yet only February and March exceeded the norm. The August 1994 through July 1995 runoff for The Dalles was 171.3 maf, 91 percent of the 1961-90 average. The peak regulated discharge for the Columbia River at The Dalles was 296,000 cfs on 19 May 1995. The 1994-95 monthly unregulated streamflows and their percent of the 1961-90 average monthly flows are shown in the following table for the Columbia River at Grand Coulee and at The Dalles. These flows have been corrected for storage in lakes and reservoirs to exclude the effects of regulation. 
Columbia River at

Grand Coulee in cfs

\begin{tabular}{lcccc}
$\begin{array}{l}\text { Time } \\
\text { Period }\end{array}$ & $\begin{array}{l}\text { Natural } \\
\text { Flow }\end{array}$ & $\begin{array}{l}\text { Percent of } \\
\text { Average }\end{array}$ & $\begin{array}{c}\text { Natural } \\
\text { Flow }\end{array}$ & $\begin{array}{c}\text { Percent of } \\
\text { Average }\end{array}$ \\
\cline { 3 - 4 } Aug 94 & 73,600 & 70 & 90,650 & 66 \\
Sep 94 & 42,160 & 65 & 60,200 & 63 \\
Oct 94 & 29,220 & 60 & 53,800 & 63 \\
Nov 94 & 24,490 & 50 & 55,560 & 61 \\
Dec 94 & 31,420 & 74 & 69,090 & 73 \\
Jan 95 & 36,220 & 88 & 87,590 & 89 \\
Feb 95 & 69,520 & 149 & 169,450 & 146 \\
Mar 95 & 83,060 & 141 & 178,030 & 126 \\
Apr 95 & 89,400 & 77 & 178,460 & 80 \\
May 95 & 225,250 & 86 & 403,560 & 96 \\
Jun 95 & 310,330 & 94 & 473,760 & 95 \\
Jul 95 & 165,150 & 86 & 238,530 & 93 \\
Operating & & & & \\
Year & 98,340 & 87 & 171,350 & 91 \\
Water & & & & \\
Year & 101,790 & 90 & 176,760 &
\end{tabular}

Columbia River at the Dalles in cfs

Percent of
Average

6

3

89

26

96

(2)

91 


\section{Seasonal Runoff Forecasts and Volumes}

Observed 1995 April through August runoff volumes, adjusted to exclude the effects of regulation of upstream storage, are listed below for eight locations in the Columbia Basin:

\section{Location}

Libby Reservoir Inflow

Duncan Reservoir Inflow

Mica Reservoir Inflow

Arrow Reservoir Inflow

Columbia River at Birchbank

Grand Coulee Reservoir Inflow

Snake River at Lower Granite Dam

Columbia River at The Dalles
Volume In 1000 Acre-Feet

6,301

1,934

10,744

21,093

37,445

53,748

22,363

86,090
Percent of

1961-90 Average

99

94

93

91

92

88

97

92

Forecasts of seasonal runoff volume, based on precipitation and snowpack data, were prepared in 1995 for a large number of locations in the Columbia River Basin and updated each month as the season advanced. Table 1 lists the April through August volume inflow forecasts for Mica, Arrow, Duncan, and Libby projects, and for unregulated runoff for the Columbia River at The Dalles. Also shown in Table 1 are the actual volumes for these five locations. The forecasts for Mica, Arrow, and Duncan inflow were prepared by B.C. Hydro, and those for the lower Columbia River and Libby inflows were prepared by the U. S. Columbia River Forecasting Service. The 1 April 1995 forecast of January through July runoff for the Columbia River above The Dalles was 99.6 maf and the actual observed runoff was 104.0 maf. 
The following tabulation summarizes monthly forecasts since 1970 of the January through July runoff for the Columbia River above The Dalles compared with the actual runoff measured in millions of acre-feet (maf). The average January-July runoff for the $1961-1990$ period is 105.9 maf.

\section{The Dalles Volume Runoff Forecasts in MAF (Jan-Jul)}

$\begin{array}{rrrrrrrr}\text { Year } & \text { Jan } & \text { Feb } & \text { Mar } & \text { Apr } & \text { May } & \text { June } & \text { Actual } \\ 1970 & 82.5 & 99.5 & 93.4 & 94.3 & 95.1 & & 95.7 \\ 1971 & 110.9 & 129.5 & 126.0 & 134.0 & 133.0 & 135.0 & 137.5 \\ 1972 & 110.1 & 128.0 & 138.7 & 146.1 & 146.0 & 146.0 & 151.7 \\ 1973 & 93.1 & 90.5 & 84.7 & 83.0 & 80.4 & 78.7 & 71.2 \\ 1974 & 123.0 & 140.0 & 146.0 & 149.0 & 147.0 & 147.0 & 156.3 \\ 1975 & 96.1 & 106.2 & 114.7 & 116.7 & 115.2 & 113.0 & 112.4 \\ 1976 & 113.0 & 116.0 & 121.0 & 124.0 & 124.0 & 124.0 & 122.8 \\ 1977 & 75.7 & 62.2 & 55.9 & 58.1 & 53.8 & 57.4 & 53.8 \\ 1978 & 120.0 & 114.0 & 108.0 & 101.0 & 104.0 & 105.0 & 105.6 \\ 1979 & 88.0 & 78.6 & 93.0 & 87.3 & 89.7 & 89.7 & 83.1 \\ 1980 & 88.9 & 88.9 & 88.9 & 89.7 & 90.6 & 97.7 & 95.8 \\ 1981 & 106.0 & 84.7 & 84.5 & 81.9 & 83.2 & 95.9 & 103.4 \\ 1982 & 110.0 & 120.0 & 126.0 & 130.0 & 131.0 & 128.0 & 129.9 \\ 1983 & 110.0 & 108.0 & 113.0 & 121.0 & 121.0 & 119.0 & 118.7 \\ 1984 & 113.0 & 103.0 & 97.6 & 102.0 & 107.0 & 114.0 & 119.1 \\ 1985 & 131.0 & 109.0 & 105.0 & 98.6 & 98.6 & 100.0 & 87.7 \\ 1986 & 96.8 & 93.3 & 103.0 & 106.0 & 108.0 & 108.0 & 108.3 \\ 1987 & 88.9 & 81.9 & 78.0 & 80.0 & 76.7 & 75.8 & 76.5 \\ 1988 & 79.2 & 74.8 & 72.7 & 74.0 & 76.1 & 75.0 & 73.7 \\ 1989 & 101.0 & 102.0 & 94.2 & 99.5 & 98.6 & 96.9 & 90.6 \\ 1990 & 86.5 & 101.0 & 104.0 & 96.0 & 96.0 & 99.5 & 99.7 \\ 1991 & 116.0 & 110.0 & 107.0 & 106.0 & 106.0 & 104.0 & 107.1 \\ 1992 & 92.6 & 89.1 & 83.5 & 71.2 & 71.2 & 67.8 & 70.4 \\ 1993 & 92.6 & 86.5 & 77.3 & 76.6 & 81.9 & 86.1 & 88.0 \\ 1994 & 79.7 & 76.3 & 78.1 & 73.2 & 75.5 & 76.4 & 75.0 \\ 1995 & 101.0 & 99.6 & 94.3 & 99.6 & 99.6 & 97.9 & 104.0\end{array}$




\section{Reservoir Operation}

\section{General}

The 1994-95 operating year was characterized by below average precipitation during August and September, and above normal during October -July. Temperatures basically were below normal November through early January, much above during February with low level melting of the snowpack, and below normal during the spring runoff period. Although the snowmelt season was characterized by below normal conditions, high March and June precipitation helped the system recover. At The Dalles, the observed January-July runoff was 98 percent of average, three percent higher than the January forecast, and four percent higher than the April forecast.

The operating year began with the coordinated reservoir system officially filling to 74.7 percent of storage capacity on 31 July 1994. As a result, third year firm energy load carrying capability (FELCC) was adopted for the 1994-95 operating year. The system continued to proportionally draft from August through February to meet FELCC. During March through July, the system load could be met operating to the Energy Content Curves (ECC) except for the second half of April when proportional draft was required to meet FELCC.

The 1 January 1995 water supply forecast for The Dalles was 101.0 maf for the January-July period, or 95 percent of the 1961-90 average. Subsequent forecasts through March reflected a decreasing trend to 89 percent, with the April forecast turning upward being 94 percent of normal. During April through July, varying precipitation gave runoff volume forecasts of $92-95$ percent of normal. Actual runoff for January-July was 98 percent of normal.

During the 10 April-31 August flow augmentation period, U.S. projects were used to augment flows at Lower Granite and McNary. The National Marine Fisheries Service's Biological Opinion, released in early March 1995, listed target flows that were variable based on runoff volume forecasts. The target flows were:

- Lower Granite, 85,000-100,000 cfs during 10 April - 20 June, and 50,000-55,000 cfs during 21 June - 31 August;

- McNary, 220,000-260,000 cfs during 20 April - 30 June, and 200,000 cfs during 1-31 August. 
Provision for adjusting target flows based on runoff volume forecasts were done on a sliding scale with Lower Granite at $95,000 \mathrm{cfs}$ and $52,000 \mathrm{cfs}$ for the two periods. McNary was at $249,000 \mathrm{cfs}$ for the first period. The second period is set at $200,000 \mathrm{cfs}$ and does not vary with runoff forecasts.

Daily flood control regulation was not required during the 1995 snow melt season. The year's observed peak flow at The Dalles was $296,000 \mathrm{cfs}$ on 19 May. Last year's peak was $224,300 \mathrm{cfs}$. The system reached 89 percent of its full energy capacity in the Actual Energy Regulation (AER) on 31 July 1995, resulting in first-year FELCC being adopted for the 1995-96 operating year. The observed refill on 31 July 1995 was 91 percent of energy capacity, providing some reservoir operating storage above the proportional draft level going into the new operating year.

\section{Mica Reservoir}

As shown in Chart 6, the Mica Reservoir (Kinbasket Lake) level was Elev. 2435.1 feet, 39.9 feet below full pool level (Elev. 2475 feet), on 31 July 1994. The reservoir continued to fill in early August, reaching its peak level for the year, Elev. 2437.9 feet, on 15 August. The reservoir level remained above Elev. 2429 feet until late October.

Mica Treaty storage was $2717 \mathrm{ksfd}$ (5.4 MAF, 77 percent of full) on 31 July 1994. Mica Treaty storage continued to fill during August, reaching a maximum of $3211 \mathrm{ksfd}$ (6.4 MAF, 91 percent of full) on 31 August. Actual Mica discharges exceeded DOP releases throughout the summer, and the Mica Treaty underrun that had accumulated prior to the summer was eliminated by the end of August.

Mica powerhouse discharges during November and December averaged about $23 \mathrm{kcfs}$, and the reservoir drafted to Elev. 2402.4 feet by 31 December 1994. Treaty storage on that date was $756.2 \mathrm{ksfd}$ (1.5 MAF).

January and February 1995 were relatively mild. In addition, B.C. Hydro released water from its Non-Treaty Storage Agreement (NTSA) account to maintain the viability of mountain whitefish eggs spawned downstream of Keenleyside. The resulting import of energy caused Mica powerhouse discharges to be very low in early 1995 , averaging $14 \mathrm{kcfs}$ in January and $8 \mathrm{kcfs}$ in February. The reservoir drafted to Elev. 2391.0 feet by 28 February, with Treaty storage empty ( $0 \mathrm{ksfd})$ on that date. 
The Mica Reservoir continued to draft during March-April and the reservoir reached its lowest level for the 1994-95 water year, Elev. 2374.8 feet, on 2 May 1995. This level was $24 \mathrm{ft}$ higher than the previous year's low level. Mica Treaty storage reached a minimum of $-497 \mathrm{ksfd} .(-1.0 \mathrm{MAF})$ on 1 May.

With the start of the spring freshet in early May, Mica discharges were reduced, and the reservoir refilled quickly reaching Elev. 2463.6 feet by 31 July. The Mica Treaty discharge was $10 \mathrm{kcfs}$ for the months' of May through July, allowing Treaty storage to refill to $2751 \mathrm{ksfd}$ (5.5 MAF, 78 percent of full) by 31 July. Actual Mica discharges during May-July averaged $3 \mathrm{kcfs}$, increasing the Mica Treaty underrun to $395 \mathrm{ksfd}$ by the end of July.

The Mica Reservoir continued to fill during the first part of August, reaching a peak level for the year of Elev. 2470.7 feet (4.3 feet below full) on 21 August. During the remainder of August and September, the reservoir was held between Elevs. 2469 and 2471 feet. Mica Treaty storage refilled completely on 13 September. The Mica Treaty underrun reached a maximum of $424 \mathrm{ksfd}$ in mid-August, but was reduced to $325 \mathrm{ksfd}$ by 30 September 1995.

\section{Revelstoke Reservoir}

During the 1994-95 operating year, the Revelstoke project was operated generally as a run-of-river plant, with the reservoir level maintained within 2.6 feet of its normal full pool level, Elev. 1880 feet. During the spring freshet, March through July, the reservoir was occasionally operated as low as Elev. 1877.4 feet to allow control of high local inflows.

\section{Arrow Reservoir}

As shown in Chart 7, the maximum Arrow Reservoir level for 1994 was Elev. 1426.5 feet on 26 July 1994. Arrow Reservoir had drafted slightly to Elev. 1426.0 feet by 31 July. On 31 July, the Arrow Treaty storage account was $2942 \mathrm{ksfd}$ (5.8 MAF, or 82 percent of full). The Arrow level was maintained in the range Elevs. 1423-1426 feet until late September.

Keenleyside discharges increased over the autumn months from an average of $24 \mathrm{kcfs}$ in October to an average of $50 \mathrm{kcfs}$ in December. The winter discharge peaked at $56 \mathrm{kcfs}$ in mid-December. Arrow 
Reservoir drafted to Elev. 1403.1 feet by 31 December 1994 and Arrow Treaty storage on that date was $1451 \mathrm{ksfd}$ (2.9 MAF, or 41 percent of full).

Arrow Reservoir continued to draft during the January-March period. For most of this period, B.C. Hydro augmented Treaty releases with Non-Treaty water in order to maintain the viability of mountain whitefish eggs spawned downstream of Keenleyside. Between 9 February and 31 March, Keenleyside was operated to maintain a minimum discharge of $25 \mathrm{kcfs}$, as ordered by the Canadian Department of Fisheries and Oceans.

Arrow Reservoir reached its lowest level for the year, Elev. 1386.6 feet, on 30 March 1995. Arrow Treaty storage reached its minimum, $977 \mathrm{ksfd}$ (1.9 MAF, or 27percent of full), several days later on 4 April 1995.

On $31 \mathrm{March}$, the Keenleyside discharge was reduced to $15 \mathrm{kcfs}$ to ensure that rainbow trout would not spawn at unnecessary high river levels. Several dewatered trout redds were kept wetted for a limited time using a pump and sprinkler system.

During April through June, Arrow was operated under the terms of the agreement on "Non-power Use of Canadian Treaty Storage" between the entities. This agreement allowed the U.S. to store and release water above proportional draft point in Canadian Treaty space, and specified non-decreasing discharges from Arrow to avoid dewatering rainbow trout redds. With a $15 \mathrm{kcfs}$ discharge throughout April, the Arrow Reservoir level rose to Elev. 1397.6 feet by 30 April.

With the start of the spring freshet, increasing discharges from the Kootenay River created a higher water surface level in the Columbia River and a backwater effect at the Norns Creek Fan, a prime spawning location for rainbow trout. Because of this, it was possible to reduce the Keenleyside discharge to $5 \mathrm{kcfs}$ from mid-May to mid-June without dewatering rainbow trout redds. The reservoir refilled to Elev. 1440.6 feet by 30 June 1995 , by which date all of the trout eggs had hatched.

The Keenleyside discharge increased substantially in late June and July as Arrow Treaty storage approached full. The Arrow Reservoir reached its highest level for the year, Elev. 1442.8 feet, on 11 July 1995. The Arrow Treaty storage content also reached its highest level for the year, $3537 \mathrm{ksfd}$ (7.0 MAF, or 99 percent of full), on this date. 
With increased Keenleyside discharges in late July and August, the Arrow Reservoir drafted to Elev. 1438.2 feet by 31 July and to Elev. 1433.7 feet by the end of August. The Keenleyside discharge peaked for the summer at $66 \mathrm{kcfs}$ in late August. By 30 September 1995, the Arrow Reservoir level had drafted to Elev. 1429.0 feet, with Treaty storage of $2928 \mathrm{ksfd}$ (5.8 MAF, or 82 percent of full).

To minimize spill at the Kootenay River plants in Canada, the Canadian and U.S. Entities agreed to a Libby-Arrow water transfer agreement in 1995. Under the agreement, Libby releases were reduced by a total of $194 \mathrm{ksfd}$ in late July and early August, and an equal amount of water was released from Arrow Reservoir. This water will be returned to Arrow Reservoir in November-December 1995.

\section{Duncan Reservoir}

As shown in Chart 8, the Duncan reservoir level was Elev. 1891.5 feet ( 0.5 feet below full) on 31 July 1994. Duncan began drafting on 6 August to allow Keenleyside discharges to be reduced and to support the Kootenay Lake level. The reservoir drafted to Elev. 1874.5 feet by 31 August 1994.

During the months of September and October, Duncan discharged an average of $6.5 \mathrm{kcfs}$ to support the Kootenay Lake level. The project discharge was reduced to minimum for most of November, but higher discharges in December were necessary to support the Kootenay Lake level. The Duncan. Reservoir level on 31 December 1994 was Elev. 1810.1 feet (11 percent of full), the lowest level on record for that time of year.

With Libby drafting heavily in January, the Duncan discharge was reduced to minimum. However, the Libby discharge was reduced to minimum from early February to late April and the remaining live storage in Duncan was drafted during these months. The Duncan Reservoir reached its lowest level for the year, Elev. 1794.7 feet (0.3 feet above empty) on 21 April 1995.

The Duncan discharge was reduced to minimum, $0.1 \mathrm{kcfs}$, on 29 April to begin refilling the reservoir. The reservoir level reached Elev. 1829.0 feet by 31 May and Elev. 1870.9 feet by 30 June. Duncan remained on minimum discharge until 14 July. At that time, the discharge was increased to slow the rate of reservoir refill. The Duncan reservoir reached Elev. 1888.4 feet (3.6 feet from full) on 31 July and continued filling slowly to full pool, Elev. 1892.0 feet, on 29 August. 
Duncan passed inflow for the remainder of August to maintain the reservoir near full pool. On 2 September, the Duncan discharge was increased to start drafting the reservoir and fill Kootenay Lake. Duncan had drafted to Elev. 1875.8 feet by 30 September 1995.

\section{Libby Reservoir}

As shown in Chart 9, Libby did not completely refill following the 1994 runoff, with Lake Koocanusa starting the operating year at Elev. 2444.4 feet, six feet higher than last year and 15 feet below full. The lake reached its peak summer level of Elev. 2447.25 feet on 5 September 1994.

An outflow of $4 \mathrm{kcfs}$ was maintained through 7 October for Montana Department of Fish, Wildlife, and Parks (MFW\&P) continuation of fishery research work.. During October through December, Libby was operated for weekly power peaking and to store water for later U.S. Fish and Wildlife Service's Biological Opinion operation, by running 12-20 kcfs on weekdays and $4 \mathrm{kcfs}$ on weekends. This operation also enabled the project to draft to its flood control level of Elev. 2411 feet by 31 December. The actual pool level reached on that date was Elev. 2409.8 feet, 47 feet higher than the Elev. 2363.1 feet proportional draft point. Inflow during the October-December period was 71 percent of normal.

With the 1 January water supply forecast being 95 percent of normal, outflow during January was in the range of 12-19 kcfs to draft to the flood control level of Elev. 2387 feet by 31 January. With the anticipation of generator unit outages through May due to bulkhead gate slot repair, the project was drafted slightly lower to Elev. 2384 feet by 31 January.

Due to decreasing runoff volume forecasts to near 90 percent of normal during February through April, Libby outflow was reduced to its minimum flow of $4 \mathrm{kcfs}$ on 4 February 1995. A minimum pool level for the year, Elev. 2380.8 feet, was reached on 18 February. With near normal inflows during February and March, the pool remained near Elev. 2381-2382 feet. The 15 March pool level was Elev. 2381.5 feet, 5.4 feet below the flood control level of Elev. 2386.9 feet. By 28 April, after maintaining 4 kcfs outflow, Libby reached an actual pool level of 2385.6 feet, close to its flood control level of Elev. 2385.0 feet. PDP for this date was 2363.9 feet.

On 29 April, the Libby outflow was adjusted between 4 and $10 \mathrm{kcfs}$ to provide a Bonners Ferry flow of $15 \mathrm{kcfs}$ in accordance with the U.S. Fish and Wildlife Service's Biological Opinion to enhance white sturgeon spawning. Between 13 and 15 May, following field observations of sturgeon spawning, the 
Kootenai River Steering Committee requested Libby outflow be ramped up to $20 \mathrm{kcfs}$, the maximum turbine capacity at Libby project as one unit was out of service and expected to remain out through November 1995. Because of the unit outage, this year's USFWS BiOp specified $20 \mathrm{kcfs}$ from Libby rather than the $35 \mathrm{kcfs}$ at Bonners Ferry as originally proposed by the fishery agencies. The $20 \mathrm{kcfs}$ was held through 26 June ( 42 days), when the outflow was stepped down to $8.5 \mathrm{kcfs}$ by 5 July to maintain an 11 kcfs flow at Bonners Ferry through 15 July (11 days).

During 18 July - 4 August, after TMT recommended a $20 \mathrm{kcfs}$ flow from Libby tọ provide flow augmentation for salmon in the lower.Columbia River. A Libby-Arrow transfer was agreed upon to reduce releases at Libby preventing spill at the lower Kootenay River projects. During that period, Libby released flows in the range of $4-16 \mathrm{kcfs}$, reducing the release by $194 \mathrm{ksfd}$ or about 8.5 feet in the reservoir. The maximum level for the season was Elev. 2456.8 feet, 2.2 feet below full pool, reached on 30 July 1995 . The April-July runoff resulted in Libby inflows of 97 percent of normal.

The first two weeks of August saw Libby releasing $16 \mathrm{kcfs}$ for lower Columbia River flow augmentation. During last half of August through 13 September Libby released inflow, but less than 10 kcfs, as MFW\&P was conducting fishery research in the river. By 14 September, outflow was reduced to 4 kcfs for further MFW\&P fishery research, boat ramp work at Bonners Ferry, and bridge pier removal downstream of Libby Dam. The observed pool level on 30 September 1995 was Elev. 2453.8 feet, while the PDP was Elev. 2452.0 feet. The April - August seasonal runoff was near normal at 99 percent.

\section{Kootenay Lake}

As shown in Chart 10, the level of Kootenay Lake at Queens Bay was Elev. 1743.2 feet on 31 July 1994, and the level at Nelson was already below the late summer IJC maximum level of Elev. 1743.32 feet. Discharges were adjusted to pass inflow during August.

During September, the Kootenay Lake discharge was adjusted to keep the downstream Brilliant plant at full load without spill, approximately $19 \mathrm{kcfs}$. The lake level dropped to a low of Elev. 1741.6 feet (3.7 feet below the IJC level) on 4 November. By 31 December 1994, the lake had filled slightly to Elev. 1742.2 feet.

With higher Libby discharges in January, Kootenay Lake continued to fill, reaching Elev. 1743.1 feet by 29 January 1995. From this date, the lake was drafted to avoid violating the IJC Order, reaching its 
lowest level for the year, Elev. 1738.6 feet, on 24 April. In late April, local inflow to Kootenay Lake began to increase, and the lake level exceeded the IJC level, Elev. 1739.32 feet, on 4 May despite maximum discharge at Corra Linn.

Inflows to Kootenay Lake increased throughout May, and the lake reached its peak level for the year, Elev. 1749.8 feet, on 7 June. Although the basin snowpack was slightly below average, this peak lake level was the third-highest since the beginning of Libby operation in 1973. Contributing factors included the timing of runoff (high snowmelt, followed by a rainstorm) and the high Libby releases to encourage white sturgeon spawning and recruitment.

With receding runoff in the latter part of June and reduced Libby discharges in July, Kootenay Lake drafted, with the Nelson gauge level dropping below the IIC summer level of Elev. 1743.32 feet in mid-July. From this date until 31 August, discharges were adjusted to pass inflow, holding the lake level fairly constant. During September, Kootenay Lake discharges were set to avoid spill at Brilliant, and the lake refilled to Elev. 1744.2 feet by 30 September 1995.

\section{Storage Transfer Agreements}

In the 1994-95 operating year, the Canadian and U.S. Entities entered into a storage transfer agreement for the summer of 1995 in which increased releases from Canadian Treaty projects were used to reduce the outflow from Libby. This operation resulted in about $194 \mathrm{ksfd}$ less water being released from Libby during July-August, reducing the amount of spill at Canadian powerplants on the Kootenay River. This water will be returned to Columbia River Treaty Storage by 31 December 1995. 


\section{Power and Flood Control Accomplishments}

\section{General}

During the period covered by this report, Duncan, Arrow, and Mica reservoirs were operated in accordance with the Columbia River Treaty. Specifically, the operation of the reservoirs was governed by the:

1. "Detailed Operating Plan for Columbia River Treaty Storage - 1 August 1994 through 31 July 1995," (DOP) dated August 1994.

2. “Columbia River Treaty Flood Control Operating Plan," dated October 1972.

3. "Columbia River Treaty Entity Agreement On Operation of Treaty Storage for Non-Power Uses for January 1, 1995 through July 31, 1995."

Consistent with all Detailed Operating Plans (DOP) prepared since the installation of generation at Mica, the 1994-95 DOP was designed to achieve optimum power generation at-site in Canada and downstream in Canada and the United States, in accordance with paragraph 7 of Annex $A$ of the Treaty. As contemplated in the March 1991 Entity Agreement on "Options for the Development of the Detailed Operating Plan for Operating Year 1994-95", the 1994-95 Options for Development of the Detailed Operating Plan, prepared in January 1991, was used as the basis for the preparation of the 1994-95 DOP.

During the period covered by this report, Libby reservoir was operated in accordance with the 1972 "Columbia River Treaty Flood Control Operating Plan," as amended by the U.S.Army Corps of Engineers (ACE) "Review of Flood Control, Columbia River Basin, Columbia River \& Tributaries Study, CRT-63", dated June 1981, and the Entity agreement on Non-Power Uses. During a portion of the year, Libby was operated for power requirements according to the DOP, and during the remainder of the operating year Libby operated for storage and releases required for endangered White Sturgeon and Salmon as required by both the U.S. Fish and Wildlife Service and the National Marine Fishery Service Biological Opinions. The Canadian Entity has given notice that it considers the BiOp fishery operation to be inconsistent with the DOP and Columbia River Treaty. 


\section{Power Deliveries}

The Canadian Entitlement to downstream power benefits from Duncan, Arrow and Mica for the 1994-95 operating year had been purchased in 1964 by the Columbia Storage Power Exchange (CSPE). In accordance with the Canadian Entitlement Exchange Agreement dated 13 August 1964, the U.S. Entity delivered capacity and energy to the CSPE participants. The generation at downstream projects in the United States, delivered under the Canadian Entitlement Exchange, was 279 average megawatts from 1 August 1994 through 31 March 1995 and 268 average megawatts from 1 April through 31 July 1995. Capacity deliveries were up to 666 megawatts from 1 August 1994 through 31 March 1995 and 576 megawatts from 1 April through 31 July 1995.

In accordance with the March 1991 Entity Agreement on the Determination of Downstream Power Benefits, the Canadian Entity delivered to the U.S. Entity 2.0 average MW of average annual energy and no dependable capacity during the period 1 August 1994 through 31 July 1995. This energy delivery is required by Section 7 of the August 1964 Canadian Entitlement Purchase Agreement.

In accordance with the 1994-95 DOP, and as required in the March 1991 Entity Agreement on "Options for Development of the Detailed Operating Plan for Operating Year 1994-95", the U.S. Entity delivered to the Canadian Entity 20.9 megawatts of average annual energy, minus 3 percent losses, and no dependable capacity, during the period 1 August 1994 through 31 July 1995. This energy represents the increase in the purchases portion of the Canadian Entitlement resulting from including the effect of firm energy shifting in the Assured Operating Plan.

\section{Power Operations}

The Coordinated System storage level at the beginning of the 1994-95 operating year was 74.7 percent full which resulted in the System adopting a 3rd-year firm energy load carrying capability (FELCC) from the critical period studies. Due to persistent low inflows the system continued to proportionally draft from August through February to meet FELCC. The system produced surplus energy during March through 15 April, and again during May through July when Arrow and Grand Coulee refilled to their Operating Rule Curve (ORC), but most head water reservoirs operated on minimum flow trying to refill and were unable to recover to their ORC elevation by the end of July. The system storage energy 
reached 89.2 percent full on 31 July 1995, and the system adopted 1st-year FELCC from the 1995-96 PNCA Final Regulation study.

The following table shows the status of the energy stored in Coordinated System reservoirs at the end of each month compared to the ORC, whichever controlled, during the 1994-95 operating year. Normal full Coordinated System reservoir storage energy is approximately 63,700 megawatt-months (MWMo). All figures are $1000 \mathrm{MW}-\mathrm{Mo}$.

\section{END OF PERIOD ENERGY STORAGE}

\begin{tabular}{|r|ccc|ccc|}
\hline \multicolumn{3}{|c|}{ Coordinated System Storage } & \multicolumn{3}{c|}{ Canadian Treaty Storage } \\
\hline Period & $\begin{array}{c}\text { ORC/PDP } \\
\text { (K-MWmo) }\end{array}$ & $\begin{array}{c}\text { Actual } \\
\text { (K-MWmo) }\end{array}$ & $\begin{array}{c}\text { Difference } \\
\text { (K-MWmo) }\end{array}$ & $\begin{array}{c}\text { ORC/PDP } \\
\text { (K-MWmo) }\end{array}$ & $\begin{array}{c}\text { Actual } \\
\text { (K-MWmo) }\end{array}$ & $\begin{array}{c}\text { Difference } \\
\text { (K-MWmo) }\end{array}$ \\
\hline Aug-94 & 46.3 & 47.7 & 1.4 & 16.9 & 16.8 & -0.1 \\
Sep-94 & 40.3 & 45.0 & 4.7 & 14.2 & 14.6 & 0.4 \\
Oct-94 & 34.7 & 39.9 & 5.2 & 11.7 & 12.4 & 0.7 \\
Nov-94 & 28.5 & 34.3 & 5.8 & 8.8 & 10.0 & 1.2 \\
Dec-94 & 23.2 & 29.8 & 6.6 & 6.8 & 6.5 & -0.3 \\
Jan-95 & 17.6 & 25.0 & 7.4 & 5.3 & 4.8 & -0.5 \\
Feb-95 & 19.9 & 23.6 & 3.7 & 5.0 & 3.5 & -1.5 \\
Mar-95 & 14.5 & 23.3 & 8.8 & 2.1 & 1.9 & -0.2 \\
Apr-95 & 14.4 & 22.6 & 8.2 & 1.1 & 1.6 & 0.5 \\
May-95 & -28.1 & 36.7 & 8.6 & 6.7 & 6.5 & -0.2 \\
Jun-95 & 51.1 & 54.6 & 3.5 & 15.9 & 15.3 & -0.6 \\
Jul-95 & 57.0 & 59.0 & 2.0 & 20.1 & 19.7 & -0.4 \\
\hline
\end{tabular}

During October and November 1994, BPA and BCH discussed an agreement that would have allowed BPA to store water at Arrow in exchange for additional releases from Libby. This agreement would have allowed Kootenay Lake to be held higher during the autumn and winter of 1994-95. In anticipation of this agreement, storage above PDP was allowed in Treaty reservoirs during OctoberNovember. The agreement was not completed, however, and Treaty storage above PDP was released by the end of December 1994.

Treaty operations during the period December 1994 through April 1995 were planned to facilitate meeting fisheries objectives in Canada and the U.S. These objectives covered mountain whitefish and rainbow trout spawning in Canada between Keenleyside Dam and the border, and Flow Augmentation storage of up to 1 MAF (subject to flood control limits) for U.S. salmon objectives. The Treaty reservoirs were provisionally drafted between December and March to meet whitefish spawning objectives and to allow BPA to store energy in Non-Treaty Storage. The Actual Energy Regulation (AER) flows in January 
and February were generally lower than the flow objectives for whitefish, thereby requiring provisional draft and Non-Treaty storage releases by BCH to make up the difference. The U.S. salmon objective of 1 MAF of storage in Arrow reservoir on 20 April for flow augmentation was not achieved as flood control operations precluded storage above the operating rule curve.

By 30 April, the AER level had dropped and Arrow's Treaty elevation was approximately 0.8 MAF above the AER elevation. During the May-June period, this water was released to augment Lower Columbia River streamflows for salmon migration in a manner consistent with Canadian needs for trout spawning and dust storm avoidance. Arrow discharge was reduced to $5 \mathrm{kcfs}$ by the end of May, as Lower Columbia River salmon flow targets were met primarily with higher Snake River flows and tributary flows below Arrow. This also allowed Arrow Lake to fill in a steady manner. Arrow's outflow was then gradually increased in June, from 5 kcfs to 32 kcfs. The Arrow Treaty elevation increased from Elev. 1400 feet on 30 April to Elev. 1441 feet by 30 June, with no significant draft of Arrow during the flow augmentation release period in keeping with the Arrow Lake level enhancement objective. July operations generally passed inflow as Arrow approached it's Treaty full elevation of 1444 feet. The operation according to the Entity Non-Power uses agreement was deemed a success by both parties as the flow augmentation storage release occurred in a manner that met Canadian trout spawning, Arrow Lake level, and refill objectives and the U.S. salmon objective.

Throughout the 1994-95 operating year, BPA developed and implemented an extensive purchasing strategy to meet projected energy deficits, to store for flow augmentatioh in the United States and meet other non-power requirements. The following table is a summary of federal purchases and non-firm and surplus firm sales to Northwest and Southwest utilities (in MW-months) during August 1994 through July 1995. These purchases were in addition to those provided in the operating plan for firm load requirements . under critical water conditions. 
BPA PURCHASES WITH NON-FIRM AND SURPLUS FIRM SALES (MW-Months)

\begin{tabular}{|r|r|r|r|r|r|}
\hline Period & Purchases & \multicolumn{2}{|c|}{ Sales To Northwest } & \multicolumn{2}{c|}{ Sales To Southwest } \\
\hline & & Non-Firm & Surplus Firm & Non-Firm & \multicolumn{1}{|c|}{ Surplus Firm } \\
Aug 94 & 1890 & 0 & 0 & 0 & 296 \\
Sep 94 & 2090 & 0 & 0 & 0 & 110 \\
Oct 94 & 2029 & 0 & 143 & 0 & 654 \\
Nov 94 & 1956 & 0 & 163 & 0 & 207 \\
Dec 94 & 2121 & 163 & 0 & 216 \\
Jan 95 & 852 & 0 & 155 & 0 & 201 \\
Feb 95 & 360 & 102 & 283 & 42 & 317 \\
Mar 95 & 489 & 558 & 413 & 271 & 281 \\
Apr 95 & 121 & 295 & 301 & 98 & 416 \\
May 95 & 0 & 248 & 890 & 175 & 637 \\
Jun 95 & 188 & 559 & 1387 & 707 & 848 \\
Jul 95 & 250 & 1145 & 702 & 653 & 503 \\
\hline TOTAL & 12346 & 2907 & 4600 & 1947 & 4098 \\
\hline
\end{tabular}




\section{Flood Control}

The Columbia River Basin reservoir system, including the Columbia River Treaty projects, was not operated on a daily basis for flood control in the spring of 1995. The observed and unregulated hydrographs for the Columbia River at The Dalles between 1 April 1995 and 31 July 1995 are shown on Chart 14. The unregulated peak flow at The Dalles would have been 552,000 cfs on 7 June 1995 and it was controlled to a maximum of 296,000 cfs on 19 May 1995.

The observed peak stage at Vancouver, Washington was 9.7 feet on 16 June 1995 and the unregulated stage would have been 19.6 feet on 8 June 1995. Chart 15 documents the relative filling of Arrow and Grand Coulee during the principal filling period, and compares the regulation of these two reservoirs to guidelines in the Treaty Flood Control Operating Plan. Because of earlier minimum fishery releases and this year's runoff pattern, drafting of Arrow lakes prior to the spring runoff resulted with no flood control operation at Arrow after 30 April 1995 as the curve on Chart 15 did not guide the operation after that date.

Computations of the Initial Controlled Flow (ICF) for system flood control operation were made in accordance with the Treaty Flood Control Operating Plan. Computed Initial Controlled Flows at The Dalles was $315,000 \mathrm{cfs}$ on 1 January 1995, 318,000 cfs on 1 February, 282,000 cfs on 1 March, 299,000 cfs on 1 April, and 305,000 cfs on 1 May. As mentioned earlier, the observed peak flow at The Dalles was 295,800 cfs. Data for the 1 May ICF computation are given in Table 6. 


\section{Table 1 \\ Unregulated Runoff Volume Forecasts \\ Million of Acre-Feet \\ 1995}

\begin{tabular}{|c|c|c|c|c|c|}
\hline & Duncan & Arrow & $\underline{\text { Mica }}$ & Libby & $\begin{array}{l}\text { Columbia River at } \\
\text { The Dalles, Oregon }\end{array}$ \\
\hline $\begin{array}{c}\text { Forecast } \\
\text { Date - } \\
\text { 1st of }\end{array}$ & $\begin{array}{l}\text { Most } \\
\text { Probable } \\
1 \text { April - } \\
31 \text { August }\end{array}$ & $\begin{array}{l}\text { Most } \\
\text { Probable } \\
1 \text { April - } \\
\text { 31 August }\end{array}$ & $\begin{array}{l}\text { Most } \\
\text { Probable } \\
1 \text { April - } \\
\text { 31 August }\end{array}$ & $\begin{array}{l}\text { Most } \\
\text { Probable } \\
1 \text { April - } \\
31 \text { August }\end{array}$ & $\begin{array}{l}\text { Most } \\
\text { Probable } \\
1 \text { April - } \\
31 \text { August }\end{array}$ \\
\hline January & 2.1 & 22.7 & 10.9 & 6.1 & 88.5 \\
\hline February & 2.1 & 21.6 & 10.9 & 5.8 & 88.0 \\
\hline March & 2.1 & 21.6 & 10.9 & 5.7 & 79.3 \\
\hline April & 2.0 & 22.0 & 11.2 & 5.7 & 81.9 \\
\hline May & 2.0 & 21.7 & 10.9 & 5.7 & 81.9 \\
\hline June & 2.0 & 21.3 & 11.0 & 5.5 & 80.0 \\
\hline Actual & 1.9 & 21.1 & 10.7 & 6.3 & 86.1 \\
\hline
\end{tabular}

NOTE: These data were used in actual operations. Subsequent revisions have been made in some cases. 
Table 2

\section{Variable Refill Curve Mica Reservoir}

\begin{tabular}{|c|c|c|c|c|c|c|}
\hline Initial & $\operatorname{Jan} 1$ & Feb 1 & Mar 1 & Apr 1 & May 1 & Jun 1 \\
\hline $\begin{array}{l}\text { Probable Jan 1-31 July Inflow, Kaf } \\
\text { 95\% Forecast Error For Date, In Ksfd } \\
95 \% \text { Conf. Date-31 July inflow, Ksfd 1/ }\end{array}$ & $\begin{array}{l}9082.0 \\
4578.8 \\
682.7 \\
3896.1\end{array}$ & $\begin{array}{l}9251.0 \\
4664.0 \\
551.3 \\
3995.8\end{array}$ & $\begin{array}{l}9169.0 \\
4622.7 \\
513.4 \\
3922.3\end{array}$ & $\begin{array}{l}9335.0 \\
4706.4 \\
440.4 \\
3922.4\end{array}$ & $\begin{array}{l}9669.0 \\
4874.8 \\
440.9 \\
3672.6\end{array}$ & $\begin{array}{l}9726.0 \\
4903.5 \\
470.5 \\
2843.4\end{array}$ \\
\hline 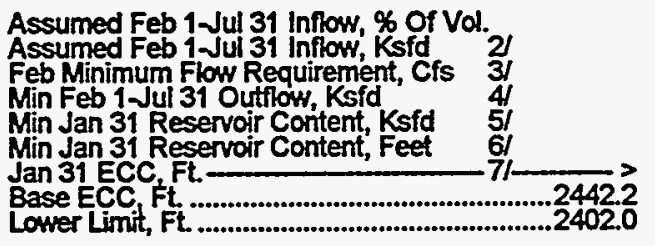 & $\begin{array}{r}100.0 \\
3896.1 \\
15000.0 \\
2486.0 \\
2119.1 \\
2442.2 \\
2442.2\end{array}$ & & & & & \\
\hline 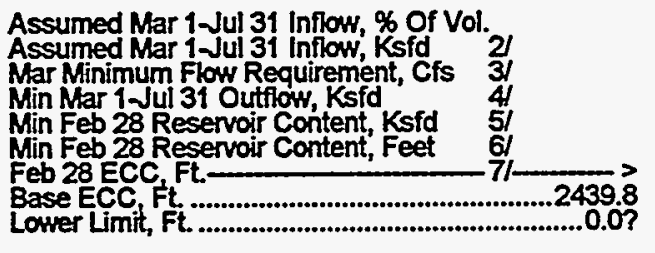 & $\begin{array}{r}97.6 \\
3802.6 \\
15000.0 \\
2066.0 \\
1792.6 \\
2435.4 \\
2435.4\end{array}$ & $\begin{array}{r}97.6 \\
3899.9 \\
15000.0 \\
2395.1 \\
2024.4 \\
2440.2 \\
2439.8\end{array}$ & & & & \\
\hline 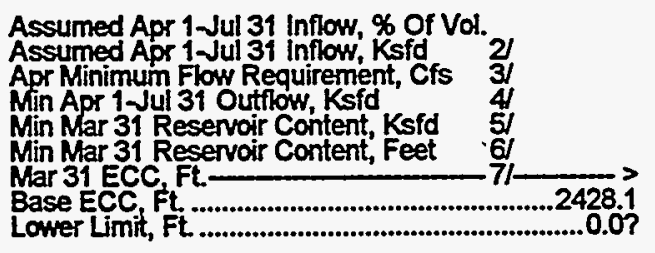 & $\begin{array}{r}95.2 \\
3709.1 \\
12500.0 \\
1601.0 \\
1421.1 \\
2427.3 \\
2427.3\end{array}$ & $\begin{array}{r}95.2 \\
3804.0 \\
12500.0 \\
1930.1 \\
1655.3 \\
2432.4 \\
2428.1\end{array}$ & $\begin{array}{r}97.6 \\
3828.1 \\
12500.0 \\
1694.0 \\
1395.1 \\
2426.7 \\
2426.7\end{array}$ & & & \\
\hline 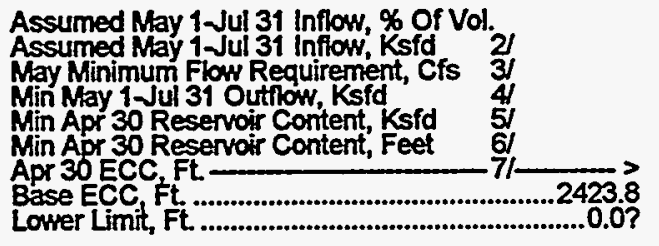 & $\begin{array}{r}90.2 \\
1514.3 \\
10000.0 \\
126.0 \\
1244.9 \\
2423.3 \\
2423.3\end{array}$ & $\begin{array}{r}90.2 \\
3604.2 \\
10000.0 \\
1555.1 \\
140.1 \\
248.1 \\
2423.8\end{array}$ & $\begin{array}{r}92.5 \\
3628.1 \\
10000.0 \\
1339.0 \\
1220.1 \\
242.9 \\
2422.9\end{array}$ & $\begin{array}{r}94.8 \\
3318.4 \\
10000.0 \\
1450.4 \\
1261.2 \\
2423.8 \\
2423.8\end{array}$ & & \\
\hline 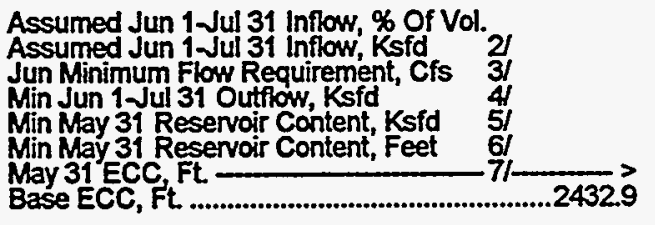 & $\begin{array}{r}72.3 \\
2816.9 \\
1400.0 \\
916.0 \\
1628.3 \\
2431.8 \\
2431.8\end{array}$ & $\begin{array}{r}72.3 \\
2869.0 \\
1866.0 \\
124.1 \\
1885.3 \\
2437.8 \\
2432.9\end{array}$ & $\begin{array}{r}74.2 \\
2990.3 \\
14000.0 \\
1009.0 \\
1627.9 \\
241.7 \\
2431.7\end{array}$ & $\begin{array}{r}76.0 \\
2981.0 \\
16933.0 \\
1140.4 \\
1688.6 \\
243.6 \\
2432.9\end{array}$ & $\begin{array}{r}80.2 \\
2945.4 \\
17533.4 \\
1186.3 \\
1770.1 \\
2434.8 \\
2432.9\end{array}$ & \\
\hline 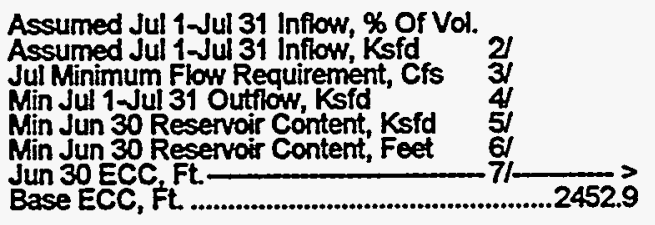 & $\begin{array}{r}35.8 \\
1394.8 \\
16000.0 \\
496.0 \\
2630.4 \\
2452.6 \\
2452.6\end{array}$ & $\begin{array}{r}35.8 \\
1460.5 \\
22100.0 \\
685.1 \\
2753.8 \\
245.6 \\
2452.9\end{array}$ & $\begin{array}{r}36.6 \\
1435.5 \\
1900.0 \\
569.0 \\
268.7 \\
2455.6 \\
2452.9\end{array}$ & $\begin{array}{r}37.6 \\
1474.8 \\
20400.0 \\
632.4 \\
2686.8 \\
2453.7 \\
2452.9\end{array}$ & $\begin{array}{r}39.6 \\
1454.4 \\
21300.0 \\
660.3 \\
2735.1 \\
2454.7 \\
2452.9\end{array}$ & $\begin{array}{r}149.4 \\
1404.6 \\
21300.0 \\
660.3 \\
2784.9 \\
2455.7 \\
2452.9\end{array}$ \\
\hline 31 ECC, Ft- & 2469.8 & 2469.8 & 2469.8 & 2469.8 & 2469.8 & 2469.8 \\
\hline \multicolumn{7}{|c|}{ 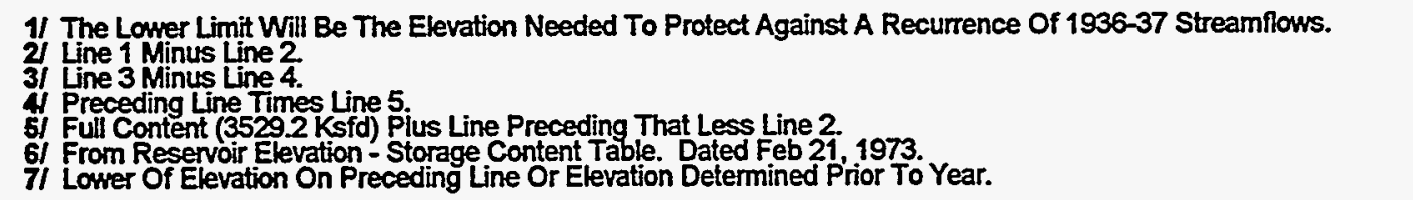 } \\
\hline
\end{tabular}


Table 3

1995 Variable Refill Curve Arrow Reservoir

\begin{tabular}{|c|c|c|c|c|c|c|}
\hline Initial & $\begin{array}{l}\text { Jan } 1 \\
\text { Local }\end{array}$ & $\begin{array}{l}\text { Feb } 1 \\
\text { Local }\end{array}$ & $\begin{array}{l}\text { Mar } 1 \\
\text { Local }\end{array}$ & $\begin{array}{l}\text { Apr } 1 \\
\text { Local }\end{array}$ & $\begin{array}{l}\text { May } 1 \\
\text { Local }\end{array}$ & $\begin{array}{l}\text { Jun } 1 \\
\text { Local }\end{array}$ \\
\hline $\begin{array}{l}\text { Probable } 1 \text { Jan-31 July Inflow, Kaf } \\
95 \% \text { Forecast Error For Date, In Ksfd Ksfd } \\
95 \% \text { Conf. Date-31 July Inflow, Ksfd }\end{array}$ & $\begin{array}{r}10378.0 \\
5232.2 \\
822.5 \\
4409.7\end{array}$ & $\begin{array}{r}10651.0 \\
5369.9 \\
645.0 \\
4407.8\end{array}$ & $\begin{array}{r}10842.0 \\
5466.2 \\
572.3 \\
4333.8\end{array}$ & $\begin{aligned} 11429.0 \\
5762.1 \\
474.5 \\
4333.3\end{aligned}$ & $\begin{array}{r}13069.0 \\
6589.0 \\
457.7 \\
3891.8\end{array}$ & $\begin{array}{r}14441.0 \\
7280.7 \\
508.1 \\
2408.0\end{array}$ \\
\hline 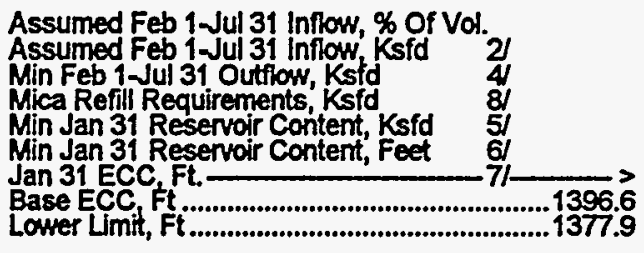 & $\begin{array}{r}103.0 \\
4542.2 \\
4374.0 \\
2486.0 \\
925.6 \\
1400.5 \\
1396.6\end{array}$ & & & & & \\
\hline 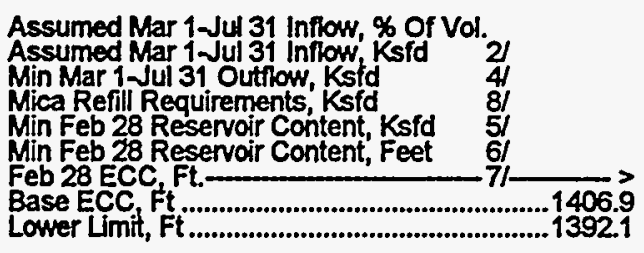 & $\begin{array}{r}100.0 \\
4409.7 \\
4234.0 \\
2066.0 \\
1337.9 \\
1408.4 \\
1406.9\end{array}$ & $\begin{array}{r}100.0 \\
4407.8 \\
4333.4 \\
2395.1 \\
1110.1 \\
1404.1 \\
1404.1\end{array}$ & & & & \\
\hline 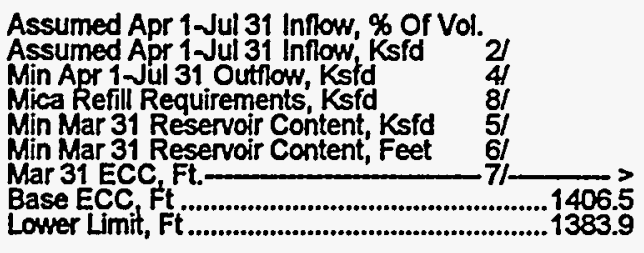 & $\begin{array}{r}97.2 \\
4286.3 \\
4079.0 \\
1601.0 \\
1771.3 \\
1416.3 \\
1406.5\end{array}$ & $\begin{array}{r}97.2 \\
4284.4 \\
4178.4 \\
1930.1 \\
1543.5 \\
1412.2 \\
1406.5\end{array}$ & $\begin{array}{r}100.0 \\
4333.8 \\
4079.0 \\
1694.0 \\
1630.8 \\
1413.8 \\
1406.5\end{array}$ & & & \\
\hline 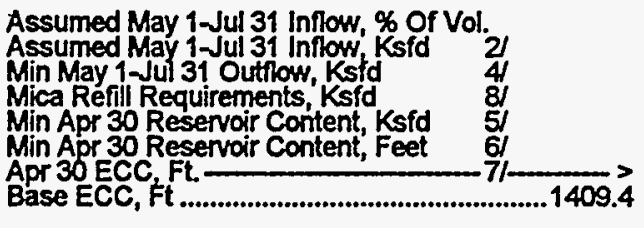 & $\begin{array}{r}93.9 \\
4140.8 \\
3614.0 \\
1226.0 \\
1826.8 \\
1417.2 \\
1409.4\end{array}$ & $\begin{array}{r}93.9 \\
4139.0 \\
3699.4 \\
1555.1 \\
1584.9 \\
1412.9 \\
1409.4\end{array}$ & $\begin{array}{r}96.5 \\
4182.1 \\
3614.0 \\
1319.0 \\
1692.5 \\
1414.9 \\
1409.4\end{array}$ & $\begin{array}{r}100.0 \\
4333.3 \\
3699.4 \\
1450.4 \\
1495.3 \\
1411.3 \\
1409.4\end{array}$ & & \\
\hline 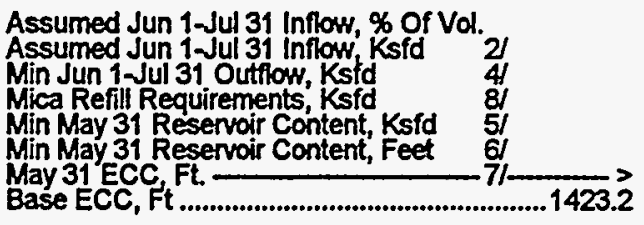 & $\begin{array}{r}85.7 \\
3779.2 \\
2808.0 \\
916.0 \\
1692.4 \\
1414.9 \\
1414.9\end{array}$ & $\begin{array}{r}85.7 \\
3777.5 \\
2864.5 \\
1245.1 \\
1421.5 \\
1409.9 \\
1409.9\end{array}$ & $\begin{array}{r}88.2 \\
3822.4 \\
2808.0 \\
1009.0 \\
1556.2 \\
1412.2 \\
1412.2\end{array}$ & $\begin{array}{r}91.4 \\
3960.6 \\
2864.5 \\
1140.4 \\
1343.1 \\
1408.5 \\
1408.5\end{array}$ & $\begin{array}{r}100.0 \\
3891.8 \\
2900.8 \\
1186.3 \\
1402.3 \\
1409.6 \\
1409.6\end{array}$ & \\
\hline 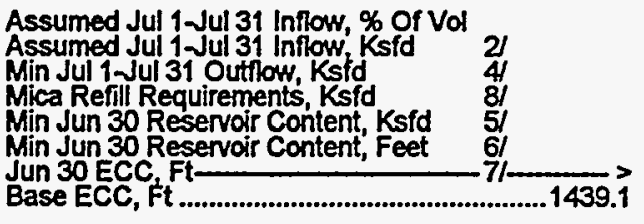 & $\begin{array}{r}61.1 \\
2694.4 \\
1488.0 \\
406.0 \\
1877.2 \\
1418.1 \\
1418.1\end{array}$ & $\begin{array}{r}61.1 \\
2693.2 \\
1502.5 \\
685.1 \\
1703.8 \\
1415.1 \\
1415.1\end{array}$ & $\begin{array}{r}62.8 \\
2721.6 \\
1488.0 \\
589.0 \\
1757.0 \\
1416.0 \\
1416.0\end{array}$ & $\begin{array}{r}65.1 \\
2821.6 \\
1502.5 \\
632.4 \\
1628.7 \\
1413.7 \\
1413.7\end{array}$ & $\begin{array}{r}71.2 \\
2770.9 \\
1511.8 \\
660.3 \\
1660.2 \\
1414.3 \\
1414.3\end{array}$ & $\begin{array}{r}100.0 \\
2408.0 \\
1511.8 \\
660.3 \\
2023.1 \\
1420.6 \\
1420.6\end{array}$ \\
\hline 1) 31 ECC, & 14 & 1444.0 & 1444.0 & & 1444.0 & 144 \\
\hline
\end{tabular}

1/ The Lower Limit Will Be The Higher of The Elevation Needed To Protect Against A Recurrence Of 1936-37 Streamflows Of The Previous Month MECC Less The Quantity One Foot Times The Number Of Days In The Current Month.

21 Line 1 Minus Line 2

4 Preceding Line Times Line 5.

5) Full Content (3579.6 Ksfd) Less Line Preceding Plus Line Preceding That Less Line Preceding That. For Arrow Total: Full Content (3579.6 Ksfd) Plus Two Preceding Lines Less Line Preceding That

6) From Reservoir Elevation - Storage Content Table. Dated Feb 21, 1973

$7 /$ Lower Of Elevation On Preceding Line Or Elevation Determined Prior To Year.

8) For Arrow Local: Mica Minimum Power Discharges. For Artow Total: Mica Full Content Less Energy Content Curve.

Table 4 


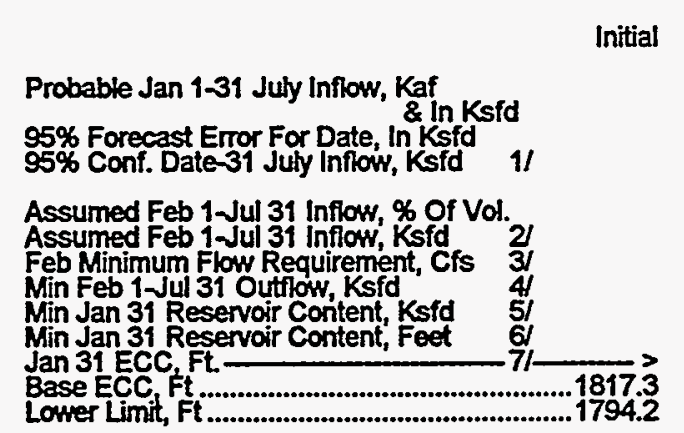

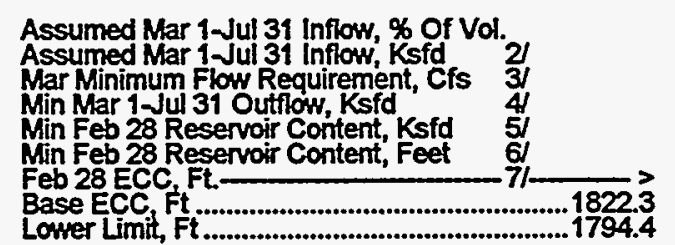

Assumed Apr 1-Jul 31 inflow, \% of Vod.

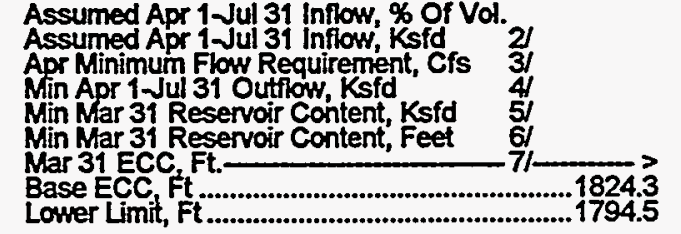

Assumed May 1 -Jul 31 Inflow, \% of Vol.

Assumed May 1 Jul 31 Inflow, Ksfd

May Minimum Flow Requirement, Cfs

Min May 1-Jul 31 Outflow, Ksfd

$\mathrm{Min}$ Apr 30 Reservoir Content, Ksfd

Min Apr 30 Reservoir Content, Feet

Apr 30 ECC, Ft

Base ECC, $\mathrm{Ft}$.

1825.9

Assumed Jun 1 Jul 31 Inflow, $\%$ of Vol

Assumed Jun 1 -Jul 31 Inflow, Ksfd

Jun Minimum Flow Requirement

Min May 31 Reservoir Content, Ksfd

Min May 31 Reservoir Content, Ksfd

May 31 ECC, Ft

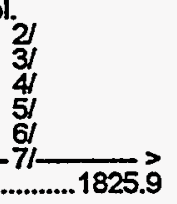

$\operatorname{Jan} 1$

Feb 1

Mar 1

Apr 1

May 1

Jun 1

1822.0

112.4

806.2

1791.0
903.0

97.8
791.1

1780.0
897.4
93.4
775.8

1797.0

906.0
91.9

1842.0
928.7
84.8
711.3

1841.0

100.0

806.2

100.0

222.9

1817.5

1817.5

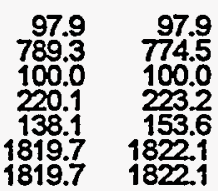

95.4
769.1

1100.0

217.0

155.2

1822.3

.

89.5
721.6
2000.0
184.0
168.2
1824.3
1824.3

95.4
754.7
1201.7

1201.7

220.1

1824.7

97.5

756.4

1150.0

218.5

167.9

1824.3

89.5

708.0

2000.0

184.0

181.8

1825.9

91.5
709.9
2000.0
184.0
179.9
1826.1
1825.9

93.8
710.7

2000.0

184.0

179.1

1826.0

1825.9

68.7
553.9
2000.0
122.0
273.9
1839.4
1839.4

68.7
543.5
2000.0
122.0
284.3
1840.9
1840.5

70.2
544.6
2000.0
122.0
283.2
1840.7
1840.5

72.0
545.5
2000.0
122.0
282.3
1840.6
1840.5

71.2

2000.0

122.0

321.4

1845.7

1845.7
32.1
253.9
2000.0
62.0
513.8
1869.7
1844.3

32.8

254.5

2000.0

62.0
513.3

513.3
1869.7

1844.3

33.7

2000.0

2000:0

512.5

1869.6

1844.3

30.4
216.2
2000.0
62.0
551.6
1874.3
1844.3

$18443 \quad 1844.3$

Jun 30 ECC 1844.3

1892.0

1892.0

1892.0

1892.0

$1892.0 \quad 1892.0$

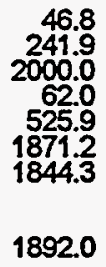

1/ The Lower Limit Will Be The Higher of The Elevation Needed To Protect Against A Recurrence Of 1936-37 Streamflows Of The Previous Month MECC Less The Quantity One Foot Times The Number Of Days in The Current Month.

2) Line 1 Minus line 2

$3 /$ Line 3 Minus Line 4.

4 Preceding Line Times Line 5.

5) Full Content (705.8 Ksfd) Plis Line Preceding That Less Line 2

6) From Reservoir Elevation - Storage Content Table. Dated Feb 21, 1973

71 Lower Of Elevation On Preceding Line Or Elevation Determined Prior To Year. 
Table 5

1995 Variable Refill Curve Libby Reservoir

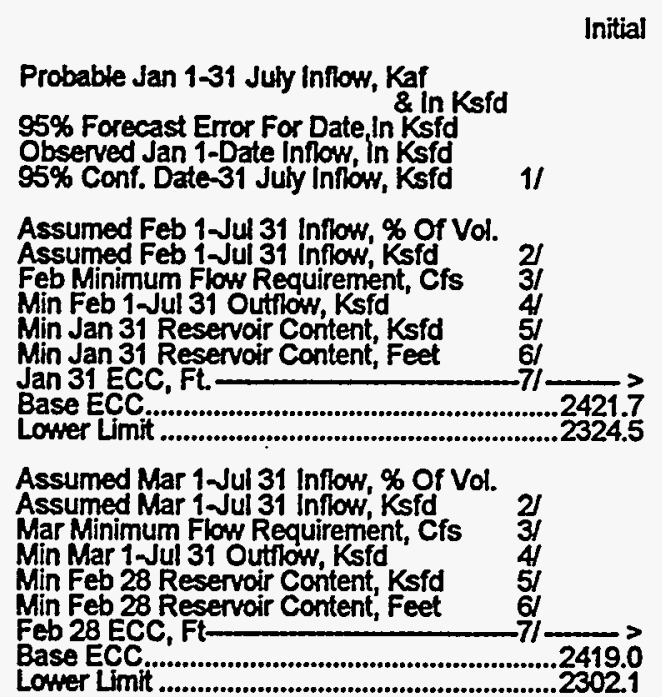

Assumed Apr 1-Jul 31 Inflow, \% of Vol.

Assumed Apr 1-Jul 31 Inflow, Ksf Apr Minimum Flow Requirement, Cfs Min Apr 1-Jul 31 Outflow, Ksfd Min Mar 31 Reservoir Content, Ksfo $M i n$ Mar 31 Reservoir Content, Feet Mar 31 ECC, Base ECC

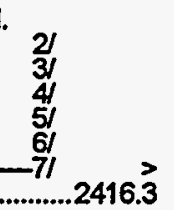

Assumed May 1 Jul 31 Inflow, $\%$ of Vol.

Assumed May 1 Jul 31 Inflow, Ksfd

Min May 1 Jul 31 Outfiow, Ksfd

Min Apr 30 Reservoir Content, Ksíd

Min Apr 30 Reservoir Content, Feet Apr 30 ECC,

Base ECC

2413.8

Assumed Jun 1 Jul 31 Inflow, \% of Vol.

Assumed Jun 1 Jul 31 Inflow, Ksid

Jun Minimum Flow Requirement, Cfs

Min Jun $1-J u l ~ 31$ Outflow, Ksfd

Min May 31 Reservoir Content Ksfo

Min May 31 Reservoir Content, Feet

May 31 ECC, Ft.

Base ECC..

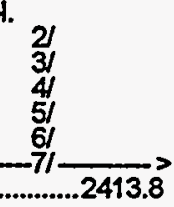

Assumed Jul 1-Jul 31 Inflow, \% of Vol

Assumed Jul 1-Jul 31 Inflow, Ksfo

Jul Minimum Flow Requirement, Cis

Min Jul 1-Jul 31 Outflow, Ksfd

Min Jun 30 Reservoir Cóntent, Ksfd

Min Jun 30 Reservoir Content, Feet

Jun 30 ECC, Ft

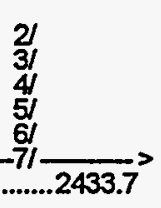

Base ECC. 2456.5

Jul 31 ECC, Ft.

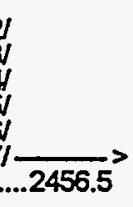

$\begin{array}{rr}\text { Feb 1 } & \text { Mar 1 } \\ 5851.0 & 5737.0 \\ 2949.9 & 2892.4 \\ 605.4 & 552.5 \\ 78.7 & 180.5 \\ 2264.8 & 2159.4\end{array}$

Apr 1
5838.0
2943.3
533.4
318.1
2091.8

May 1

5766.0

297.5

47.5

1943.0

97.1

2168.7

4600.0

1141.4

2410.0

2410.0

$\begin{array}{rr}94.5 & 97.3 \\ 2109.0 & 2202.5 \\ 4600.0 & 4693.3 \\ 1012.6 & 1015.5 \\ 1414.1 & 1323.5 \\ 2406.0 & 2400.8 \\ 2406.0 & 2400.8\end{array}$

91.2

2036.9

5000.0

1370.0

2401.9

2401.9

83.2
1857.7
6000.0
705.0
1357.8
2402.8
2402.8

85.7

1939.8

6000.0

705.0

2397.8

2397.8

56.9

1269.4

8000.0

519.0

1760.1

2424.4

57.5

1302.3

8000.0

519.0

1727.2

2422.8

19.4
433.3
9000.0
279.0
2356.2
2452.3
2452.3

20.0

9000.0

279.0

279.0

2451.5

2451.4

$2459.0 \quad 2459.0$

2459.0
96.6

000.0

870.0

1295.

2399.0

88.1

1902.0

6000.0

705.0

1313.5

59.1
1276.9
8000.0
519.0
1752.6
2424.0
2424.0

61.2

1280.

519.0

1748.9

2423.8

2423.8

20.5
443.5
9000.0
279.0
2346.0
2451.8
2451.8

21.3
444.9

9000.0

279.0

2344 .6

2451.8

2451.8

2459.0

2459.0

$1 /$ Expected Inflow Minus (95\% Error \& Jan1-Date Inflow).

21 Preceding Line Times Line 1

3) Based On Power Discharge Requirements, Determined From $8 /$.

4 Cumulative Minimum Outilow From 31, From Date To July.

5) Full Content (2510.5 Ksfd). Plus 4/. And Minus 21

6/ Elev. From 5), Interp. From NWPP Storage Content Table.

71 Elev. From d', But Limited < Base ECC, \& > ECC Lower Limit.

Jun 1

5593.0

2819.8

1146.0

1306.3
67.1

1304.3

519.0

1725.2

2422.7

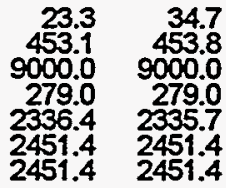

2459.0 


\section{Table 6}

Computation of Initial Controlled Flow Columbia River at The Dalles

1 May 1995

1 May Forecast of May-August Unregulated

Runoff Volume, MAF

Less Estimated Depletions, MAF

Less Upstream Storage Corrections, MAF

MICA

ARROW

5.000

DUNCAN

LIBBY 2.825

LIBBY + DUNCAN UNDER DRAFT

0.000

HUNGRY HORSE

FLATHEAD LAKE

0.000

NOXON RAPIDS

0.000

PEND OREILLE LAKE

0.000

GRAND COULEE

2.320

BROWNLEE

0.250

DWORSHAK

0.534

JOHN DAY

$\underline{0.100}$

TOTAL

Forecast of Adjusted Residual Runoff Volume, MAF

Computed Initial Controlled Flow from Chart 1 of Flood Control Operating Plan, 1,000 cfs 


\section{Chart 1}

\section{Seasonal Precipitation}

Columbia River Basin

October 1994 - March 1995

Percent of $1961-1990$ Average

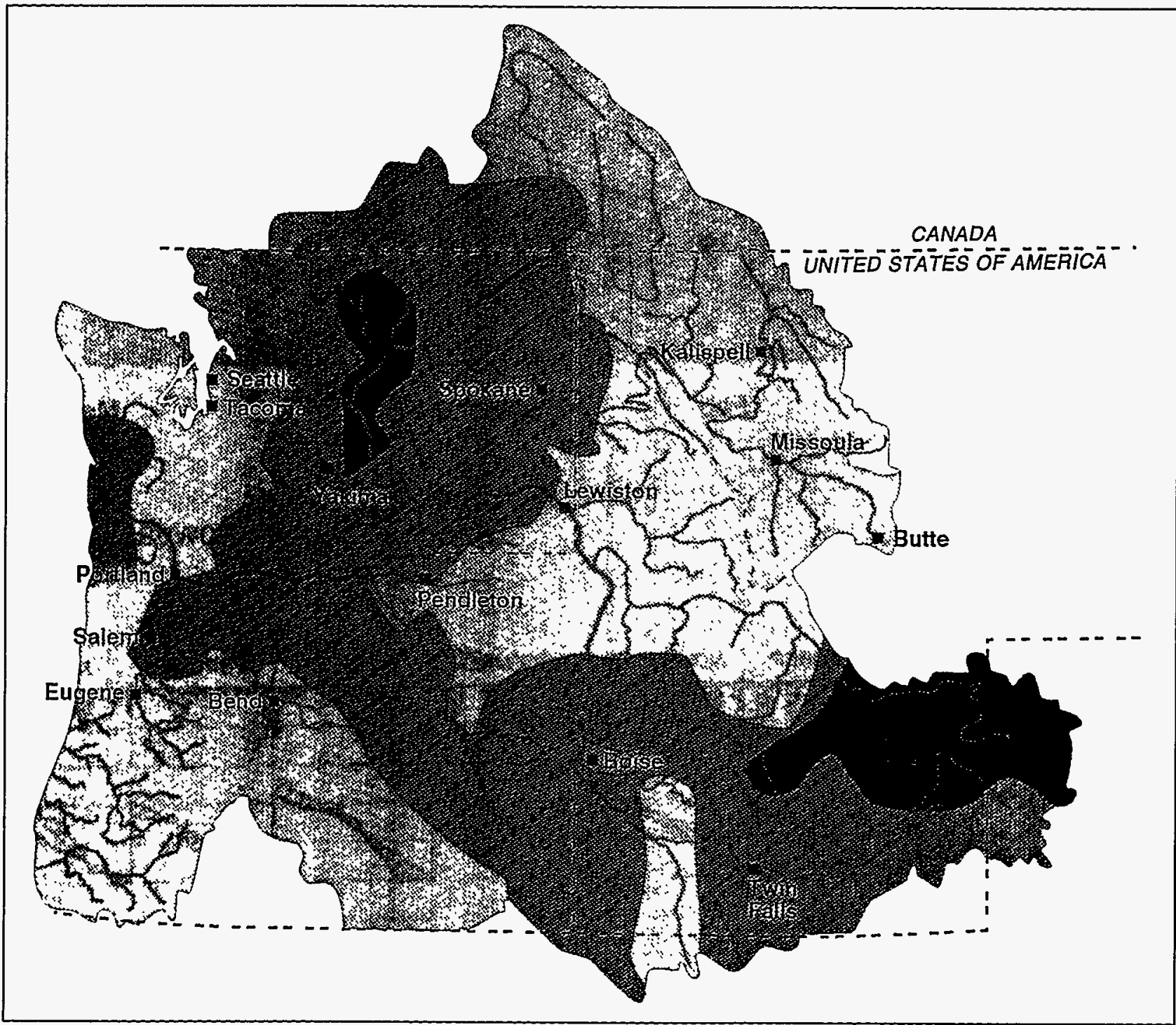

Precipitation very high and more than $150 \%$ of average

Precipitation high and more than $120 \%$ of average

Precipitation near normal and more than $80 \%$ of average

Precipitation low and more than $50 \%$ of average

Precipitation very low and less than $50 \%$ of average
Information prepared by NATIONAL WEATHER SERVICE Northwest River Forcast Center Portland, Oregon 


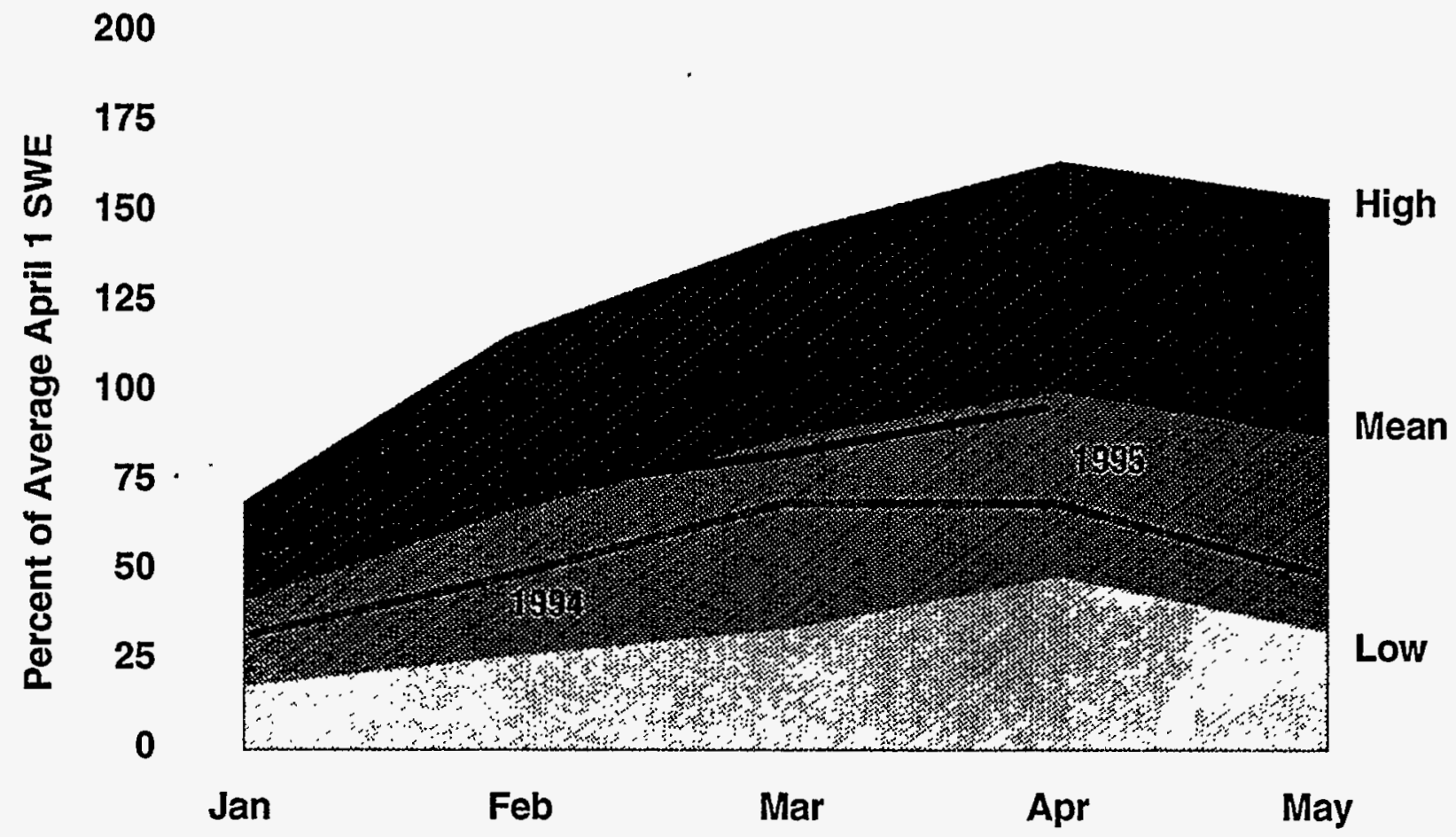

Chart 2

Columbia Basin Snowpack

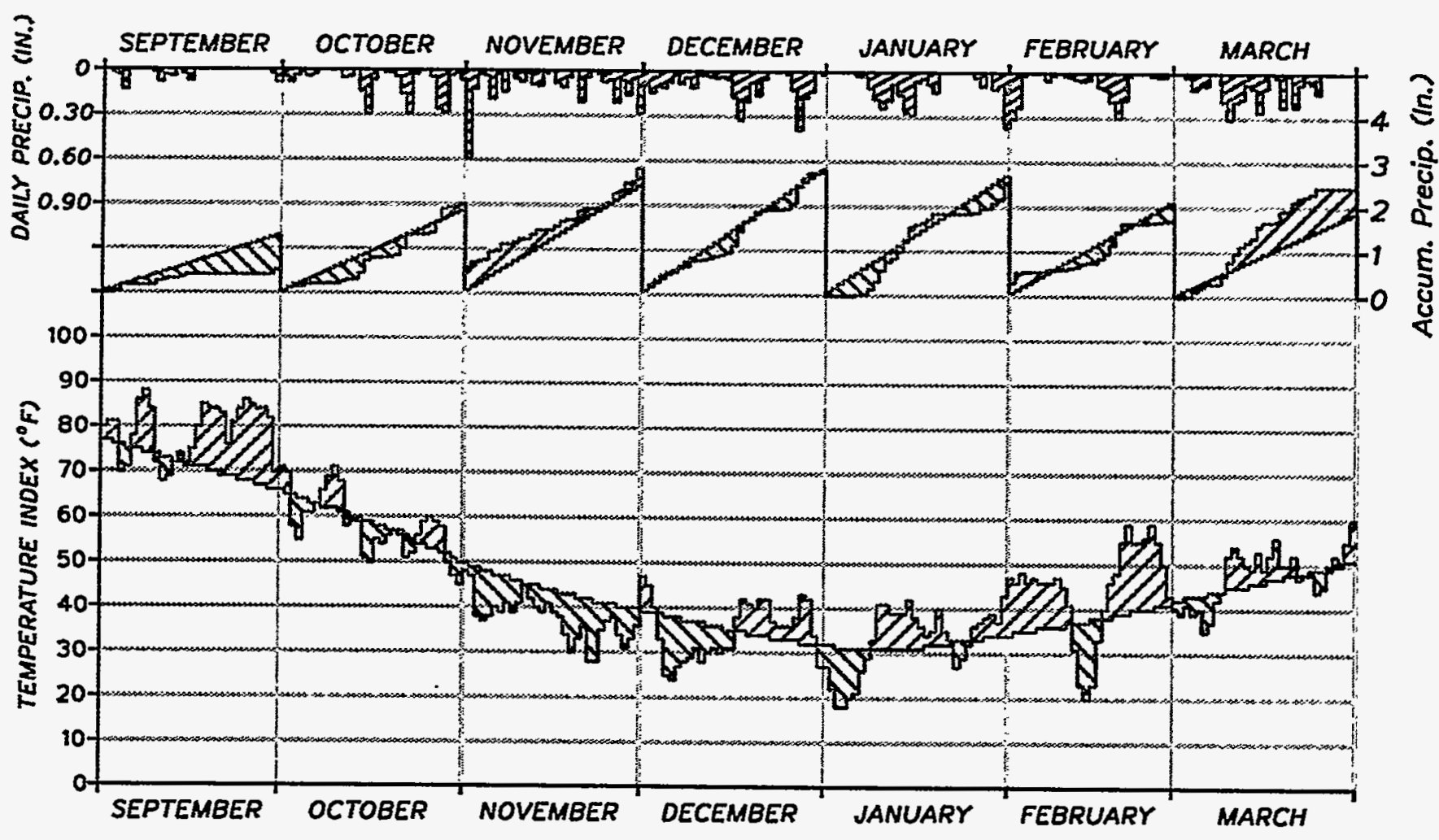



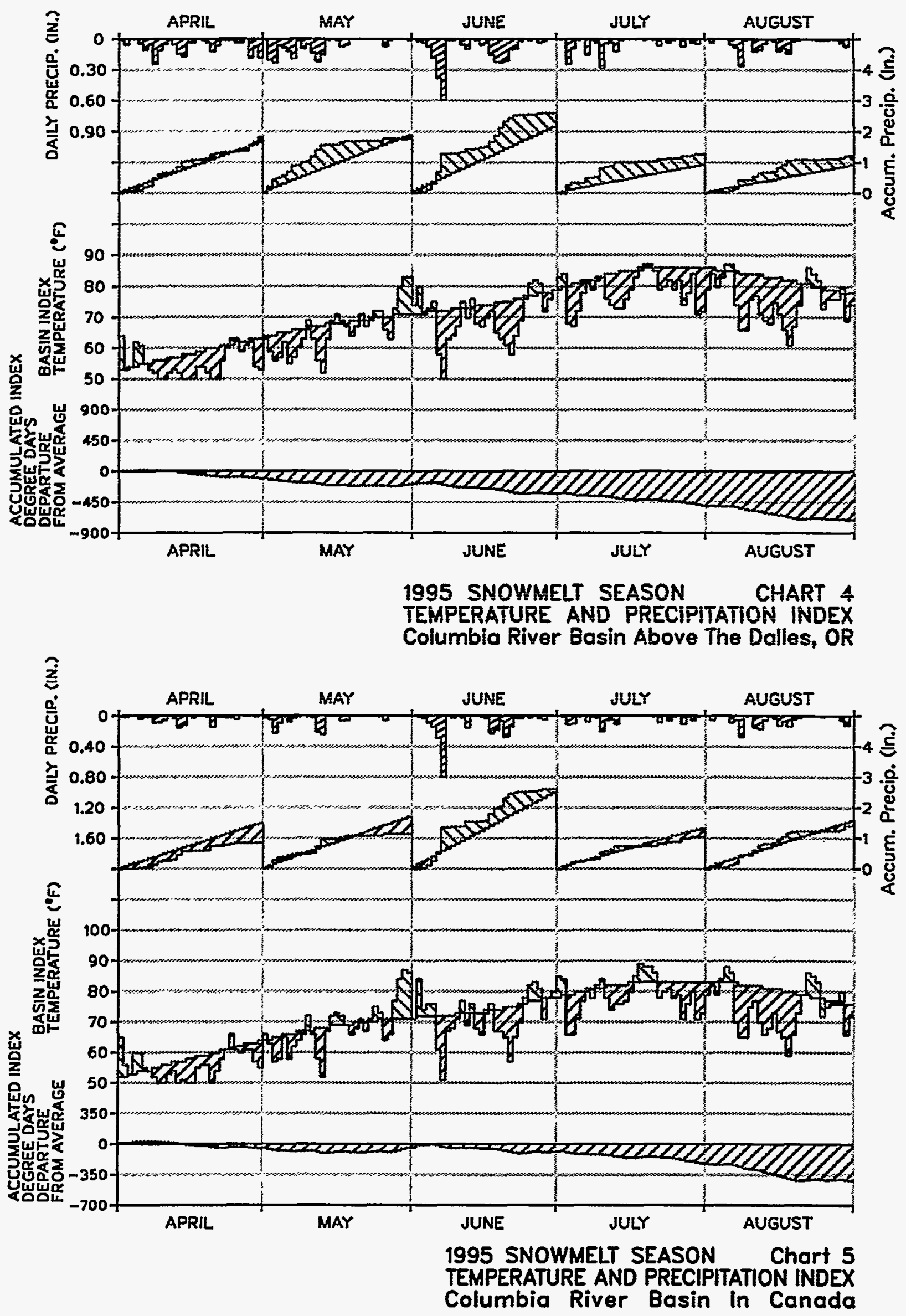
Chart 6

Regulation of Mica

1 July 1994 - 31 July 1995
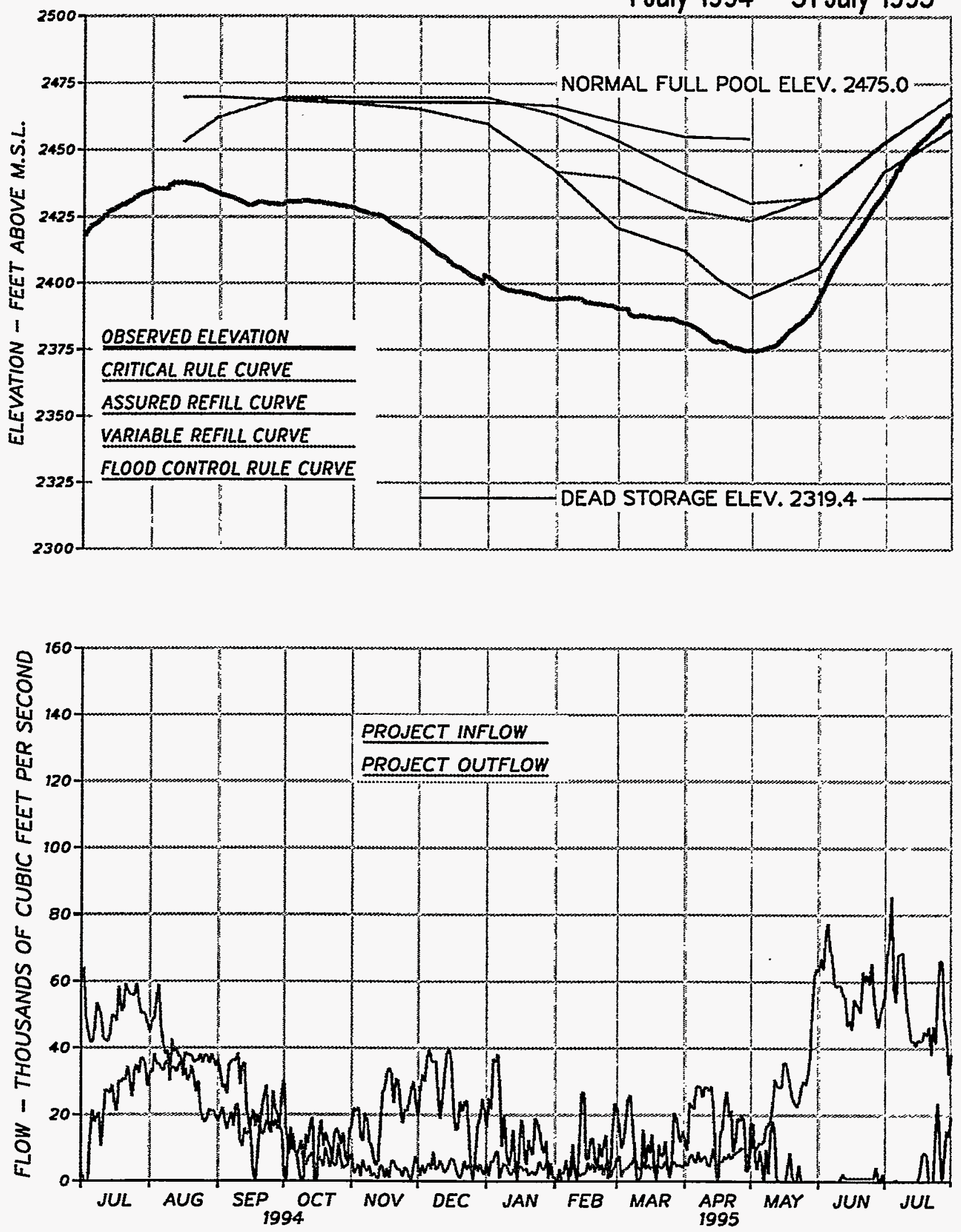
Chart 7

Regulation of Arrow 1 July 1994 - 31 July 1995
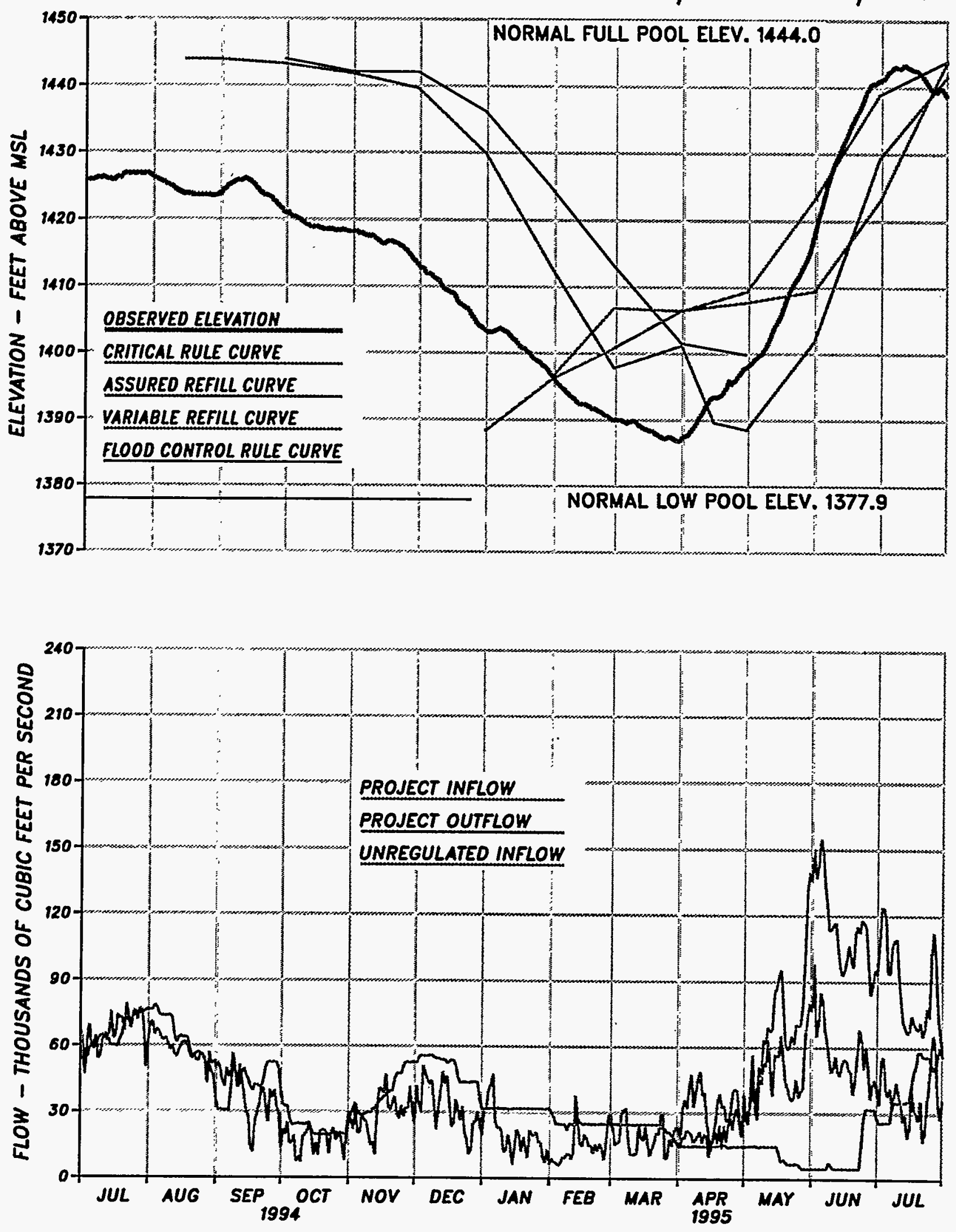
Chart 8

Regulation of Duncan

1 July 1994 - 31 July 1995
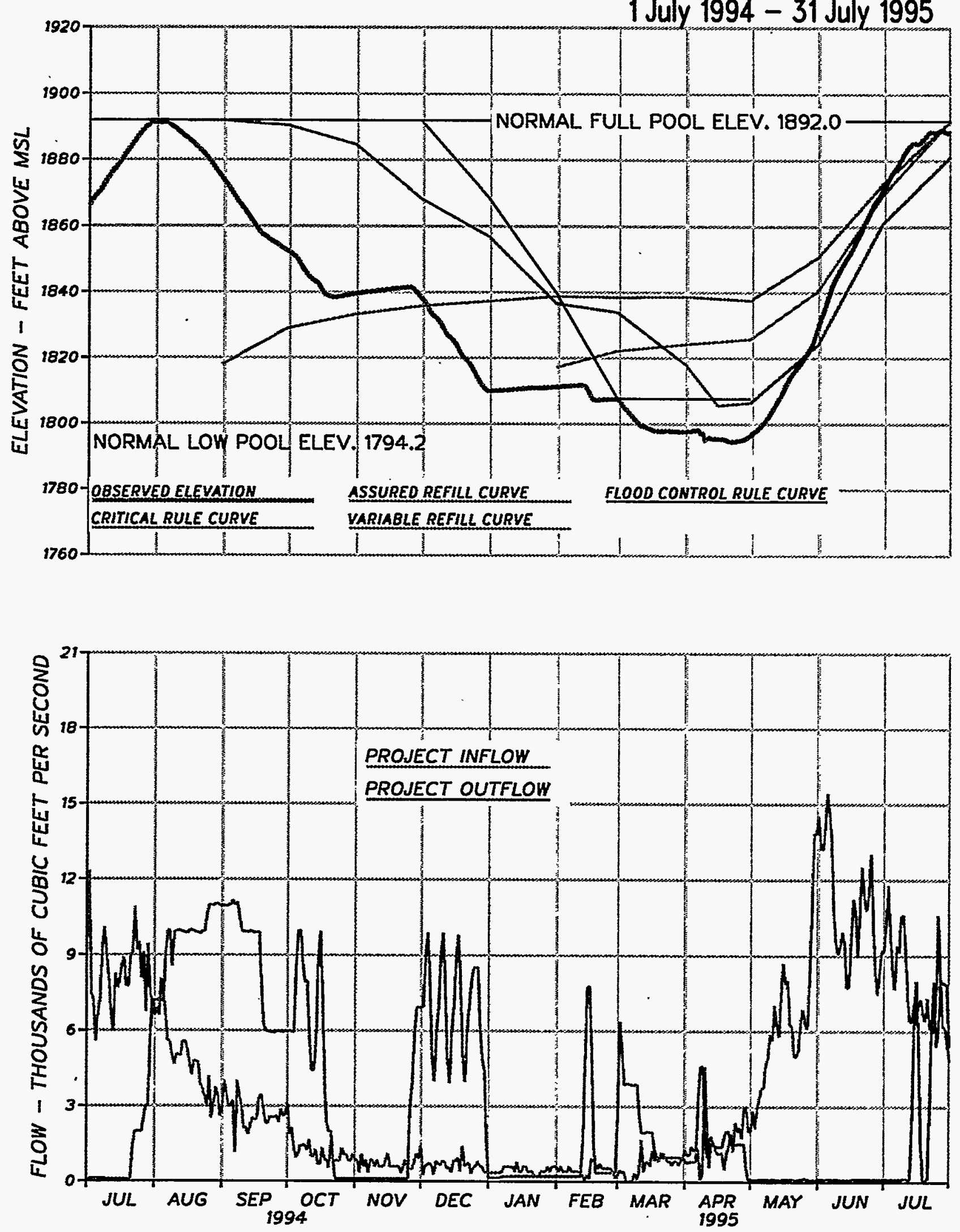
Chart 9

Regulation of Libby

1 July 1994 - 31 July 1995
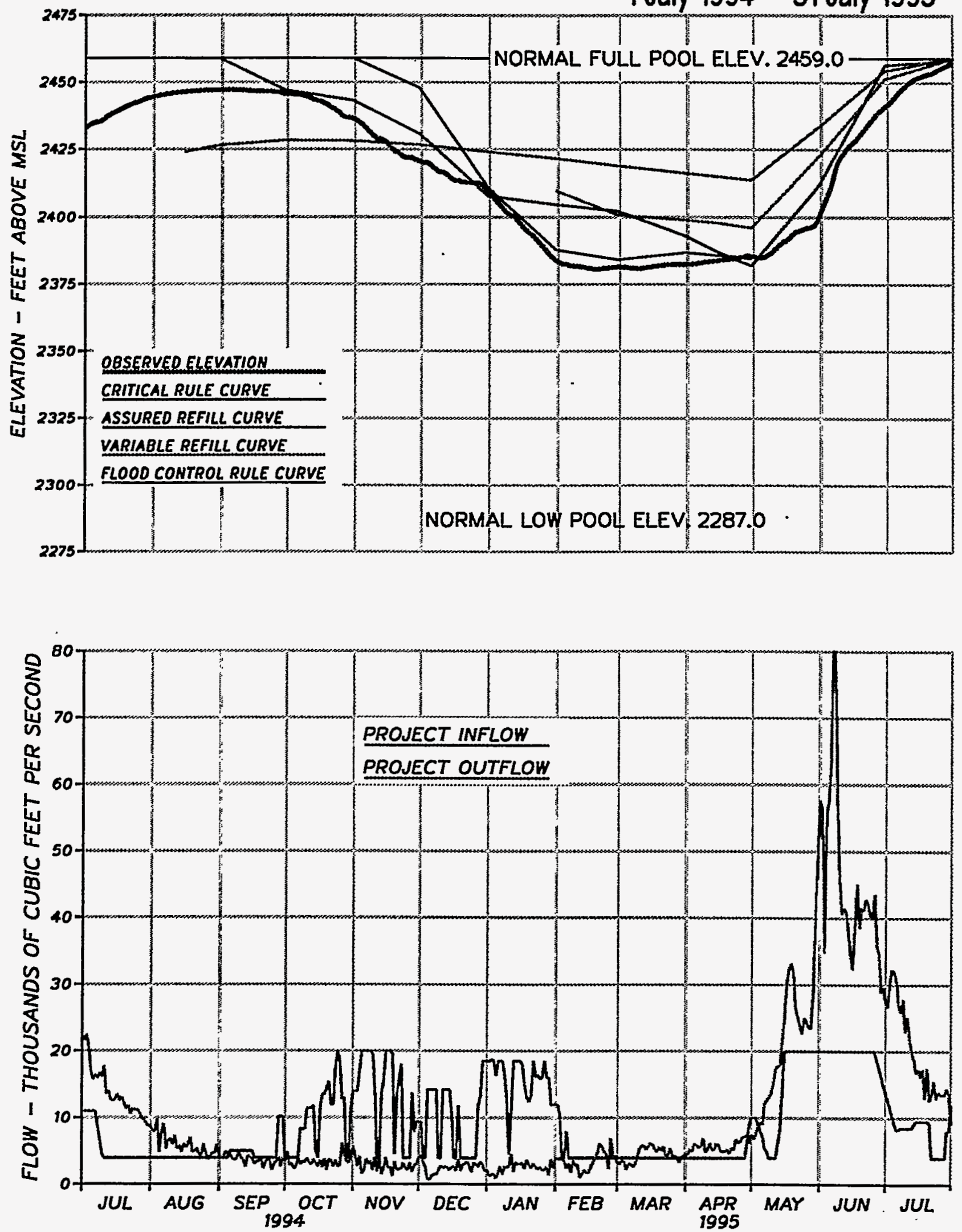
Chart 10

Regulation of Kootenay Lake

1 July 1994 - 31 July 1995
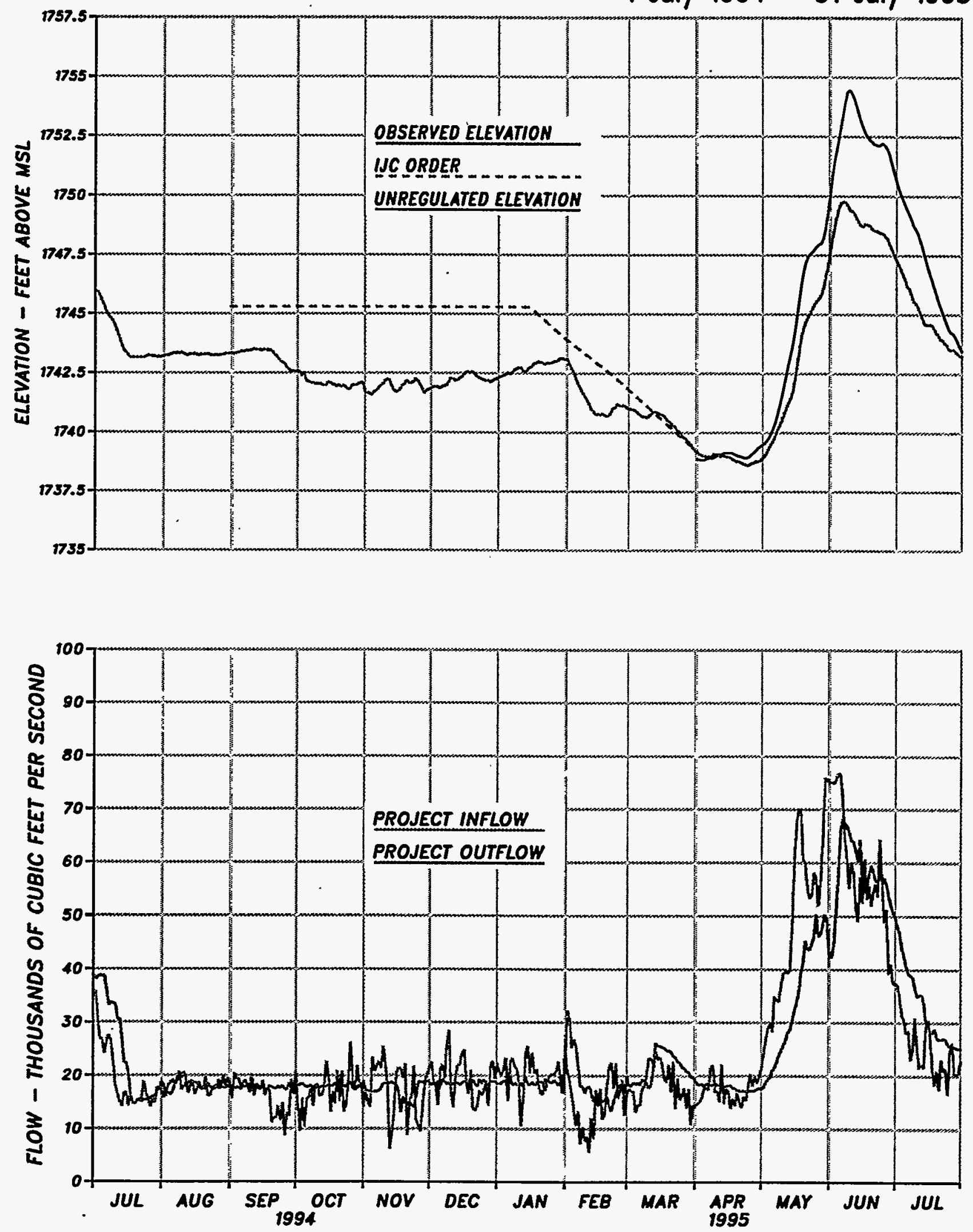
Chart 11

Columbia River at Birchbank

1 July 1994 - 31 July 1995

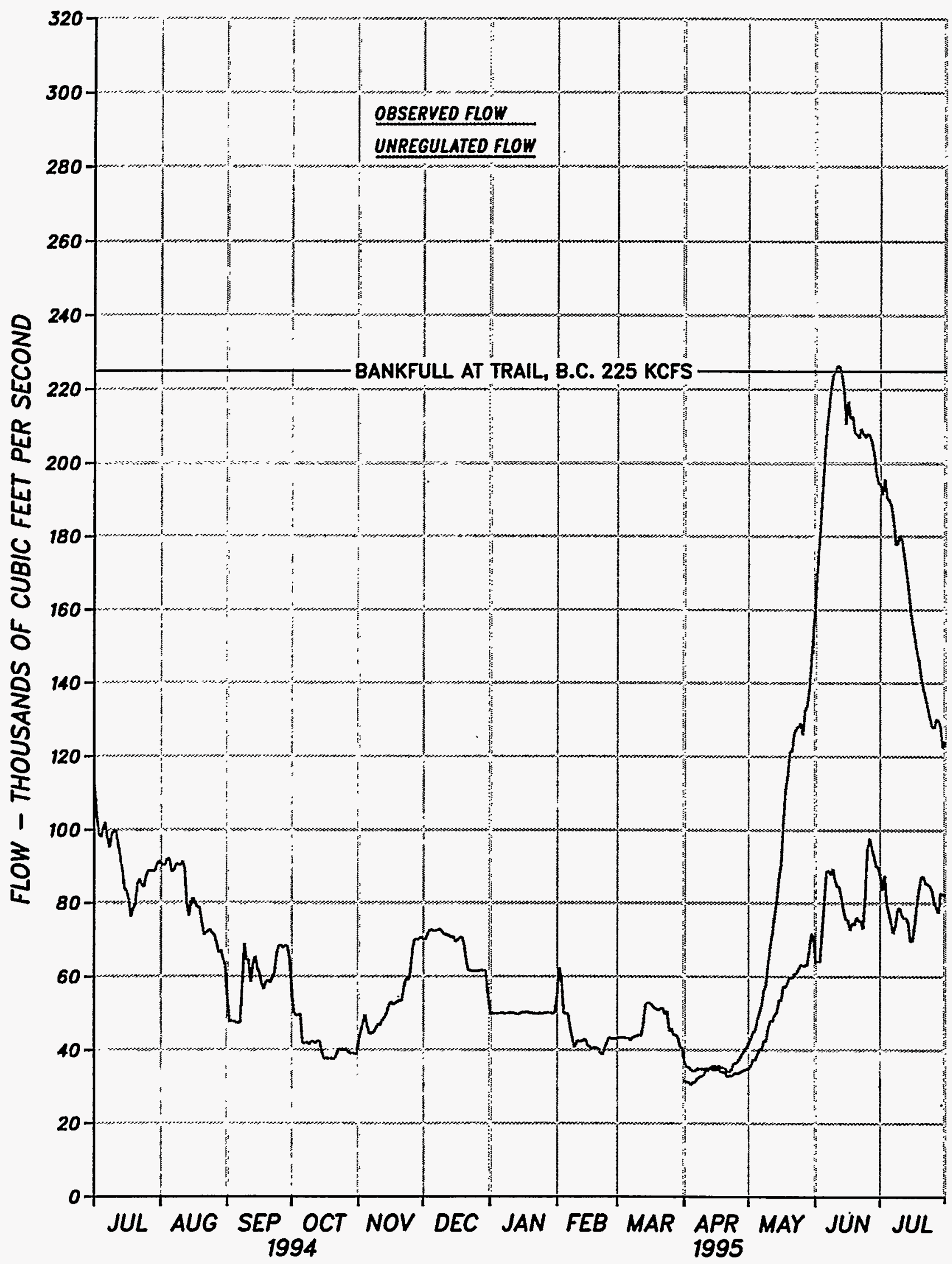


Chart 12

Regulation of Grand Coulee 1 July 1994 - 31 July 1995
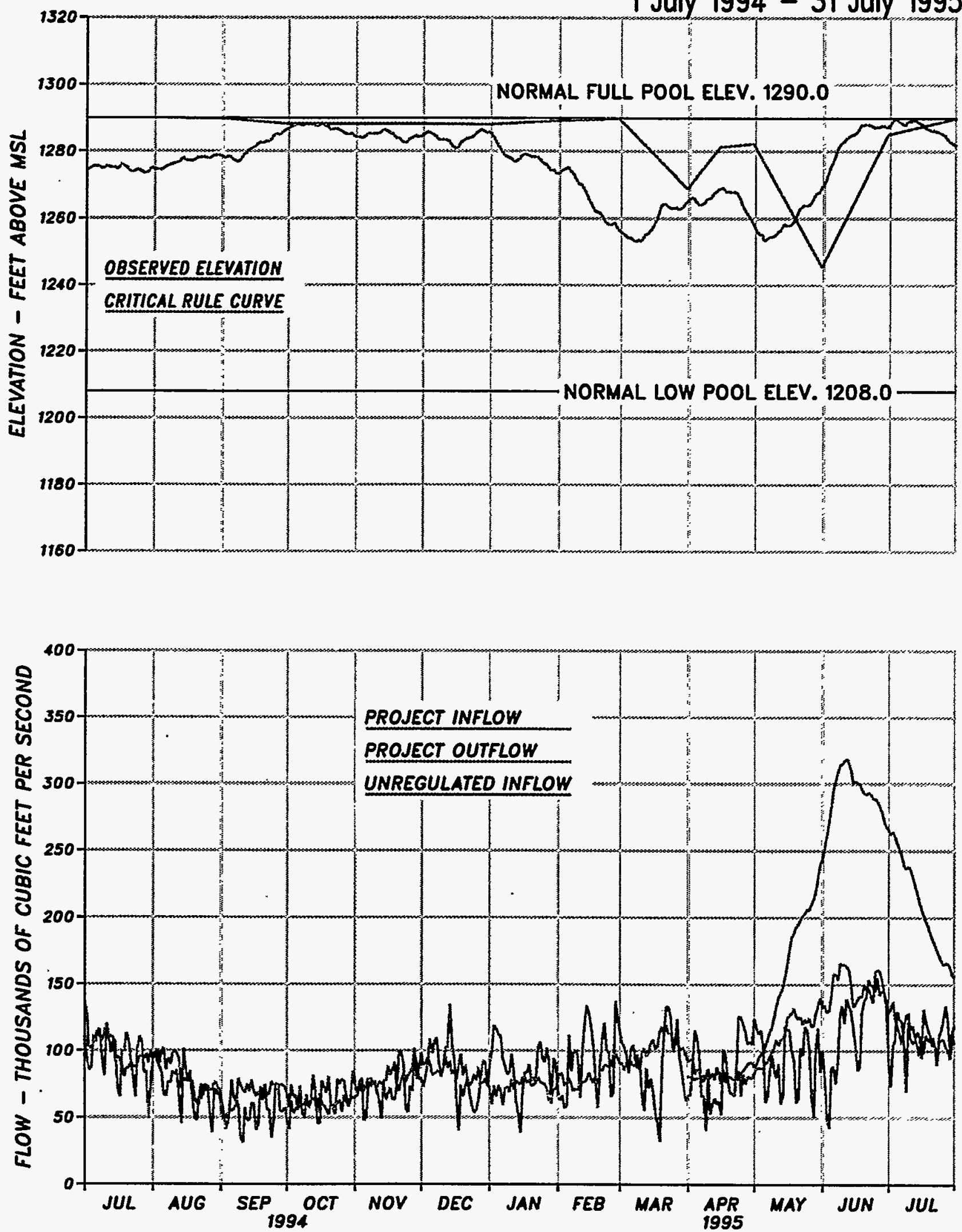


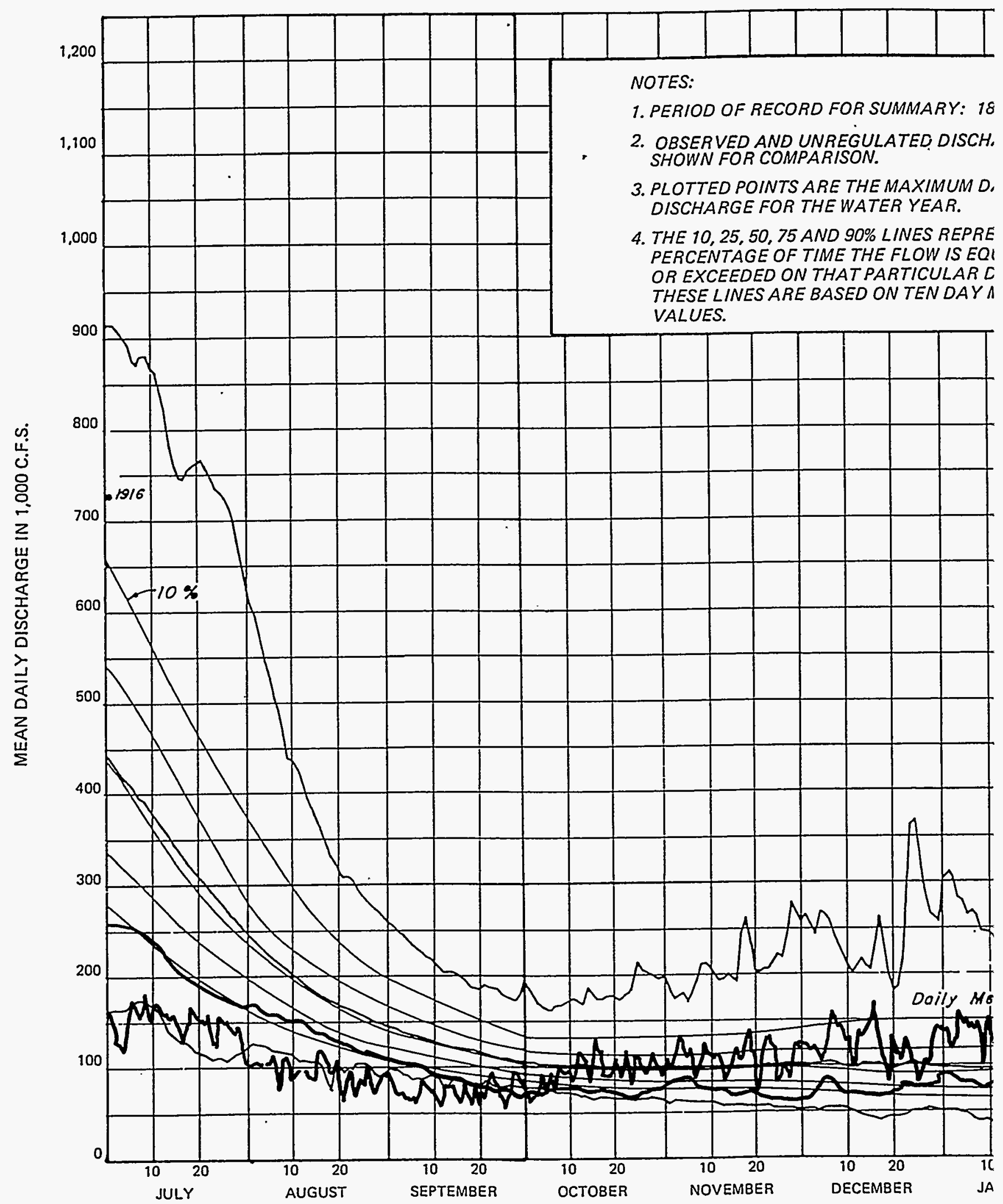


Chart 13

Columbia River at The Dalles

1 July 1994 - 31 July 1995

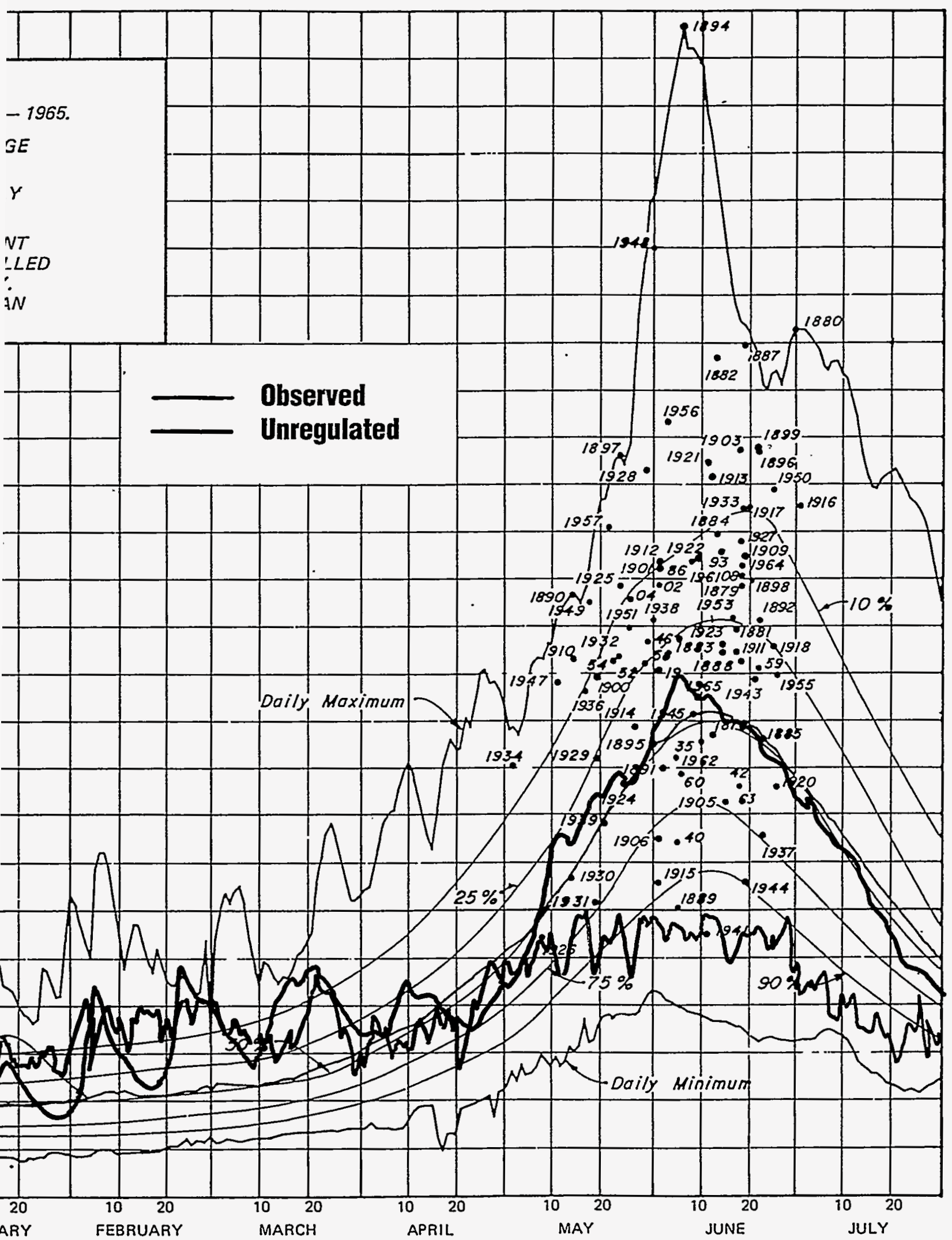


Chart 14

Columbia River at The Dalles

1 April 1995 - 31 July 1995

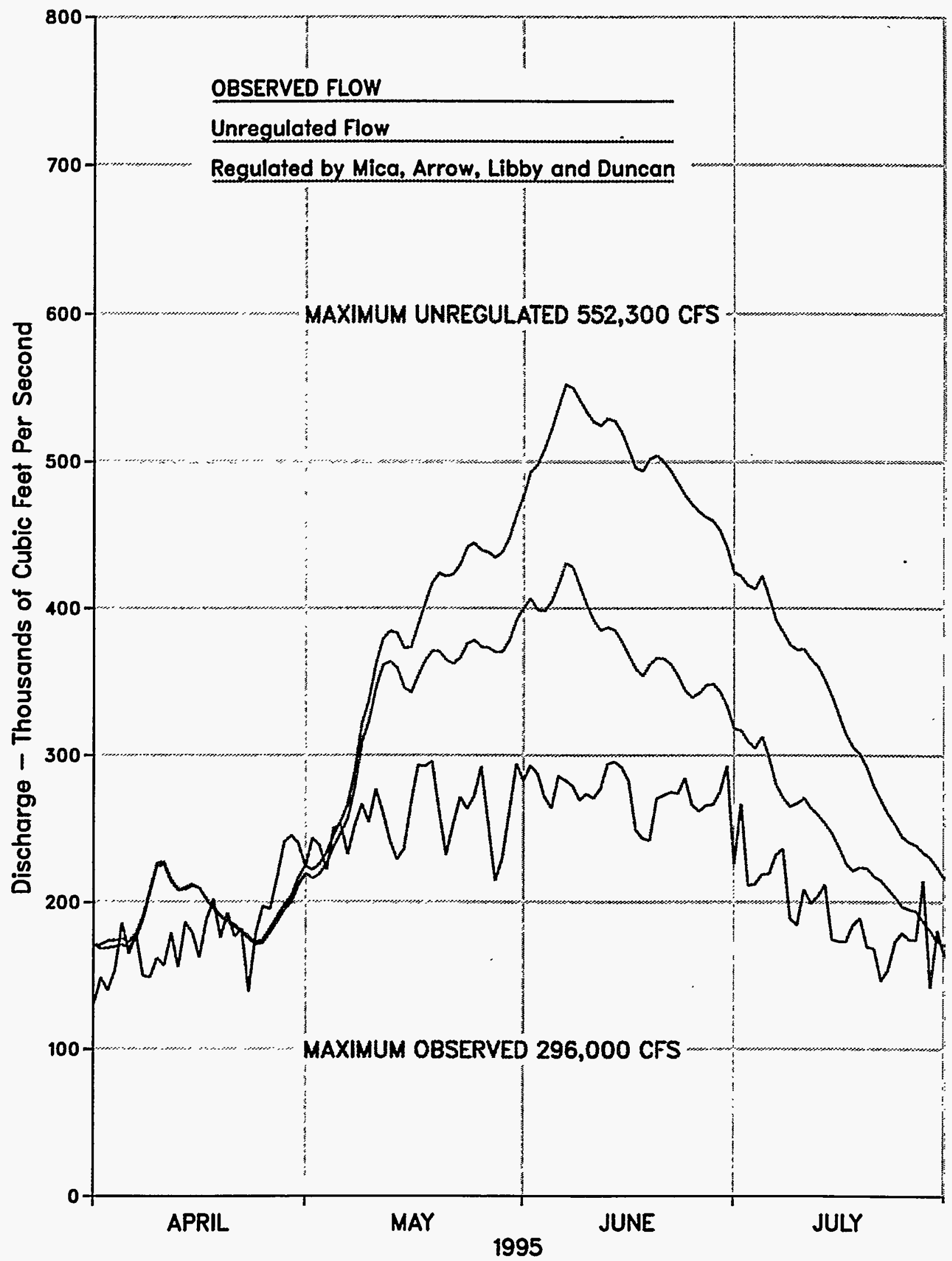


CHART 15

1995 RELATIVE FILLING

Arrow and Grand Coulee

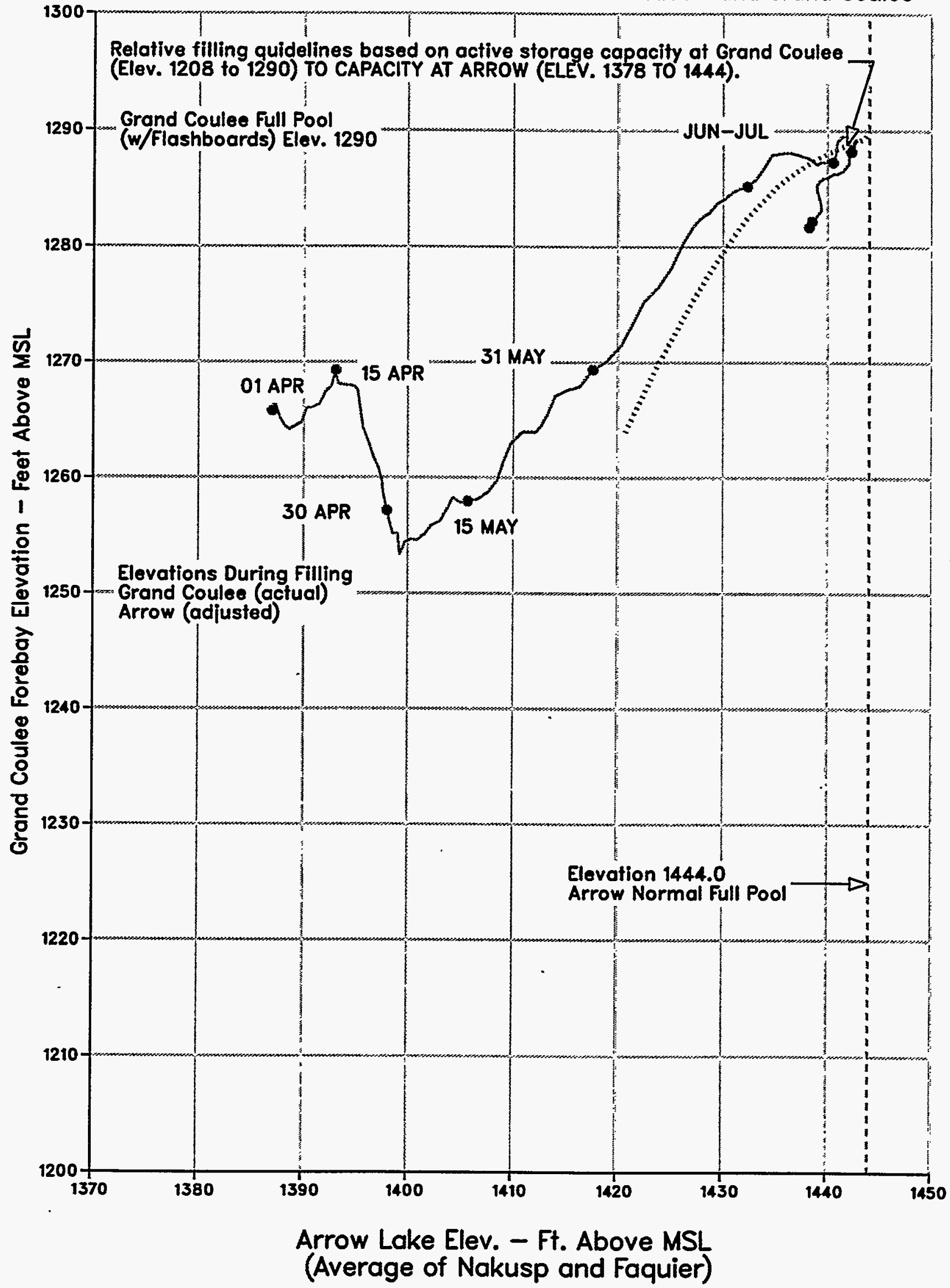

